\title{
Cultura Cultura
}

\section{Edição crítica da Écloga Piscatória de Santa Rita Durão(ou um pequeno ensaio filológico)}

Critical edition of Santa Rita Durão's Écloga Piscatória (or a brief philological essay)

\section{Marcello Moreira}

\section{OpenEdition}

\section{Journals}

\section{Edição electrónica}

URL: http://journals.openedition.org/cultura/160

DOI: $10.4000 /$ cultura.160

ISSN: 2183-2021

\section{Editora}

Centro de História da Cultura

\section{Edição impressa}

Data de publição: 1 Junho 2011

Paginação: 23-66

ISSN: 0870-4546

\section{Refêrencia eletrónica}

Marcello Moreira, "Edição crítica da Écloga Piscatória de Santa Rita Durão(ou um pequeno ensaio filológico) », Cultura [Online], Vol. 28 | 2011, posto online no dia 14 novembro 2013, consultado a 01 maio 2019. URL : http://journals.openedition.org/cultura/160 ; DOI : 10.4000/cultura.160 


\section{Edição crítica da Écloga Piscatória de Santa Rita Durão (ou um pequeno ensaio filológico)}

Marcello Moreira*

\section{Introdução}

Entre poemas setecentistas pertencentes a diversos gêneros então praticados, recolhidos em um códice membranáceo hoje depositado na biblioteca de José Mindlin, mas que pertencera ao bibliógrafo Rubem Borba de Moraes, encontra-se a única cópia conhecida da Écloga Piscatória, atribuída ao poeta Santa Rita Durão. A notícia da existência da cópia encontra-se à página 126 de Bibliografia Brasileira do Período Colonial, onde Rubem Borba de Moraes afirmava que o manuscrito em que a peça estava inscrita lhe pertencia e ainda se encontrava inédita'.

A primeira edição da Écloga Piscatória foi levada a termo por Francisco Topa, em 2002, mas não se pode dizer que seja uma edição crítica, já que não há a apresentação de critérios filológicos a partir dos quais se teria fixado o texto ${ }^{2}$ e, mais importante ainda, uma justificativa para a adoção de determinados critérios filológicos com exclusão de outros também à disposição do editor.

O que aqui se propõe é um ensaio filológico em que, a par de uma proposta de edição crítica do texto atribuído a Santa Rita Durão, se dê ao leitor interessado na poesia luso-brasileira um texto de mais fácil entendimento, porque modernizado em sua ortografia - desde que esta modernização não comprometa os componentes prosódicos, rítmicos e rímicos, por exemplo - e em sua pontuação. Os critérios para a fixação tanto do texto crítico quanto daquele outro modernizado serão apresentados em seções subseqüentes deste ensaio.

* Departamento de Estudos Lingüísticos e Literários da Universidade Estadual do Sudoeste da Bahia (moreira.marcello@gmail.com).

1 MORAES, Rubem Borba. Bibliografia Brasileira do Período Colonial. São Paulo: Instituto de Estudos Brasileiros da Universidade de São Paulo, 1969, p. 126.

2 Francisco Topa, em sua apresentação do poema, remete o leitor interessado em conhecer sua prática editorial de textos setecentistas brasileiros à edição por si preparada da Poesia Dispersa e Inédita do Setecentista Brasileiro Francisco José de Sales, edição essa publicada às expensas do editor, de difícil acesso, e que não auxilia quem a desconhece a saber quais critérios editoriais deveriam ser ou foram adotados para a fixação do texto do poema de Santa Rita Durão. 
A primeira parte deste ensaio discutirá as razões para a adoção de determinados critérios de edição a serem aplicados à produção de uma edição crítica do poema, com um paralelo arrazoado que justifique o descarte de critérios concorrentes de edição também à disposição do editor crítico. Em seguida, apresentam-se a edição crítica e a modernizada da Écloga Piscatória. Na segunda parte do ensaio, faz-se uma definição da écloga enquanto gênero do que se convencionou definir como "lírica", propondo-se as relações entre a Écloga Piscatória e a retórica epidítica e uma análise do poema atribuído a Santa Rita. Estarão também presentes na segunda parte deste ensaio as outras seções que soem compor uma edição crítica.

\section{(I)}

O Códice RBM 5 b da Coleção José Mindlin, em que se encontra a Écloga Piscatória, contém obras poéticas atribuídas a vários poetas e o índice, ao final do volume, dispõe os poemas segundo sua pertença a gêneros ou a estruturas estróficas: Index/Do que contem este Livro/(1) Cantigas; (2) Decimas; (3) Epistola; (4) Motes; (5) Odes; (6) Oitavas; (7) Poema; (8) Quintilhas; (9) Quartetos; (10) Romances); (11) Satiras; (12) Silvas; (13) Sonetos. O item de número sete parece fugir à classificação por gênero ou estrofe, já que se o nomeia "poema", vocábulo também válido para "qualificar" todos os outros textos inseridos no volume.

O Códice RMB 5 b encontra-se atualmente na Biblioteca de José Mindlim, mas pertenceu a Rubens Borba de Moraes, como o torna evidente o ex libris afixado no lado interno da capa dianteira do volume. Foi Rubens Borba de Moraes quem produziu um índice de poemas, que, no Códice, vêm atribuídos a poetas do século XVIII, contrariamente ao que sói ocorrer com a maior parte das obras, inscritas sem atribuição. Este índice está escrito em duas pequenas folhas soltas, manuscritas, que se encontram no interior do códice, entre a face interna da capa dianteira e a primeira contra-guarda. Trata-se de um códice do último quartel do século XVIII, como o evidencia a análise paleográfica a que foi submetido o manuscrito. Todo o volume foi copiado por uma única mão e é belo artefato bibliográfico-textual. A letra apresenta indiscutida elegância e pode-se dizer que se trata de livro de mão compilado por seu proprietário, ou, então, encomendado a um escriba profissional. É, sem sombra de dúvida, produto de letrado. A encadernação, realizada no século XX, ficou a cargo do famoso encadernador Marti, cujo nome está gravado na margem inferior do lado interno da capa dianteira. Apresenta as seguintes características: capas feitas de cartão, recobertas por couro verde, medindo 20,2 cm de altura e $14 \mathrm{~cm}$ de largura. O lombo, em couro, mede 20,2 cm de altura e $4 \mathrm{~cm}$ de largura; sobre o couro amarelecido da lombada, há o seguinte título gravado em ouro: POESIAS. A inscrição em ouro se encontra entre o primeiro e o segundo nervos da lombada. Há, na lombada, um total de cinco nervos, que distam em média 2,8 
$\mathrm{cm}$ um do outro. O espaço que medeia entre o requife e o nervo superiores tem $3,5 \mathrm{~cm}$, e aquele que medeia entre o nervo e o requife inferiores, $4,3 \mathrm{~cm}$. Os cortes da cabeça, da dianteira e do pé foram dourados. Como extensão dos nervos, há cinco impressões a ferro no couro verde das capas dianteira e traseira, que representam motivos fitomórficos. Os fólios que compõem o códice são de papel e medem 19,6 cm de altura e 13,6 cm de largura. A mancha no interior do volume não apresenta uniformidade, estando as páginas ora mais inscritas ora menos inscritas. Todo o Códice foi escrito em coluna única e está numerado em arábico e a numeração foi feita pelo próprio copista. O texto foi escrito por uma única mão, e diferenças notadas no talhe das letras - ora mais fino, ora mais grosso - podem ser explicadas pelo emprego, por parte do copista, de diferentes penas, ou pelo uso de uma única pena - hipótese pouco provável - apontada várias vezes. Há 325 folhas para a transcrição das obras poéticas (1-650), numeradas tanto no reto quanto no verso das folhas. Quanto ao índice (Index), há no Códice quatro folhas que se Ihe destinam, sem numeração. Algumas folhas do códice apresentam furos causados por larvas de insetos. No reto da última folha pertencente ao volume primitivo - pondo de parte guardas e contra-guardas -, foram afixadas por meio de fita adesiva três folhas soltas de tamanho menor em que estão inscritos cinco sonetos - na última destas três folhas, há apenas um soneto inscrito sobre o lado reto. O Códice não apresenta página de rosto e o poema atribuído a Santa Rita Durão ocupa as páginas 548-553. Não se pode dizer que os poemas que se seguem à Écloga Piscatória sejam de Santa Rita, pois o copista adota a prática de escrever, nas didascálias aos poemas que se seguem àquele em que se discriminou o autor, o seguinte aviso: (do mesmo autor), ou uma sua variante, aviso este, portanto, ausente dos poemas seguintes à Écloga Piscatória.

\section{II}

(II.1)

Cabe agora discutir quais critérios filológicos devem ser adotados para que se fixe o texto do poema.

Em primeiro lugar, gostaríamos de declarar que a fixação do texto por nós proposta não visa a editá-lo "na sua forma canônica, definitiva"3 aqui a ser editado -, seria preciso crer haver consenso no que respeita à produção de uma edição documentária ${ }^{4}$, que é o que proporemos para a fixação crítica do texto, em todos os tempos e lugares - o que, em termos de crítica histórica, é simplesmente absurdo.

\footnotetext{
3 SPINA, Segismundo. Introdução à Edótica. São Paulo: Ars Poetica/Edusp, 1994, p. 82.

4 Mais à frente, ficará claro o por quê de uma edição documentária poder ser uma edição crítica, proposição essa que contraria a prática editorial e crítica dominante no Brasil.
} 
Nossa intervenção crítica, fundamentada no prévio estabelecimento de procedimentos que salvaguardem, tanto quanto possível, a historicidade do testemunho a ser editado, objetiva criticar ao mesmo tempo possíveis propostas de intervenção concorrentes, que, contrariamente ao que seria de esperar e àquilo que declaram ou propõem sub-repticiamente, obliteram a historicidade do testemunho, como se verá adiante, ao constituir a partir dele um texto que espelha, tanto ou mais do que as práticas de textualização do século XVIII, ainda no âmbito de uma cultura escribal, aquelas "representativas" do editor contemporâneo e de seu "credo".

Aqui, deseja-se enfatizar as relações que as produções discursivas mantêm por necessidade com as práticas sociais, ou seja, visa-se a compreender em que medida o estado do testemunho único a ser editado, tanto do ponto de vista dos códigos lingüísticos quanto daquele dos bibliográficos, é "representativo" de práticas escribais e letradas historicamente situáveis e que deveriam ser levadas em consideração pelo editor desejoso de garantir o máximo respeito histórico ao testemunho. Nossa posição crítica, por conseguinte, ao evidenciar seu lugar institucional de análise - aquele em que a Filologia conflui, por necessidade, com a História Social, com a Sociologia e com a Bibliografia - visa ao mesmo tempo patentear as formas da crença - que são também um "fazer crer" - que têm balizado o labor filológico de base neolachmanniana em nosso país, ao explicitar as categorias analíticas de seus enunciados, que se nos apresentam como enunciações normativas e dispositivos de imposição garantidores da "cientificidade" do trabalho editorial. Se a edição crítica neolachmanniana se apresenta como estratégia discursiva de auto-legitimação e de fixação e de imposição de sentido para textos particulares, de quaisquer tempos e lugares, desejamos aqui expressar que essa imposição, transgredida pela reflexão, não visa a instituir outro paradeigma ou sistema análogo de validade trans-histórica, mas apenas investir o testemunho a ser editado de um uso possível, que é aquele de lê-lo segundo suas modalidades de produção, circulação e recepção que historicamente acabaram por constituí-lo no estado em que se nos apresenta ${ }^{5}$. A seção que ora se escreve é mais do que uma crítica ao neolachmannismo tal como vem sendo praticado em nosso país, apresenta-se como o explicitar-se de um percurso de pesquisa ou o desvelar-se de um procedimento que aqui se ajuíza o mais pertinente porque o mais "verossímil". Talvez mais do que tentar encontrar um suposto "vivido", objetiva-se compreender os restos que o tempo nos legou e, ainda mais importante, escrutinar as categorias de compreensão que, no âmbito filológico, têm tornado o pensado pensável. Visa-se assim apenas a explicitar o modo tradicional do fazer

5 CHARTIER, Roger. À Beira da Falésia. A História entre Certezas e Inquietude. Porto Alegre: Editora da UFRGS, 2002, p. 120. 
filológico e histórico sucintamente definido de modo exemplar por Michel de Certeau explicitação essa constitutiva de uma diferença, já que desse modo o "notado" pode ser problematizado filologicamente pela correlação que se estabelece entre ele, concorrentes "notações" e uma reflexão sobre o próprio "notável" nas condições atuais de produção do discurso crítico -: "Ele (o historiador e também o filólogo) parece contar os fatos, enquanto, efetivamente, enuncia sentidos que, aliás, remetem o notado (aquele que é retido como pertinente pelo historiador) a uma concepção do notável." ${ }^{6}$

\section{(II.2)}

É preciso atentar, ao lerem-se as edições críticas produzidas pelos neolachmannianos, para a idéia motriz de "autoria", desprovida de qualquer relativização histórica, e outras que lhe são complementares, como a de "genuinidade" , tomada esta última também no sentido de origem e de estranhamento poético; há, nessas edições, opção pela adoção e trans-historicização de categorias "que caracterizam, em um momento histórico particular, o regime de produção de discursos", como o é a de "autoria", categoria que também governa, no mundo contemporâneo, para muitos de nós, nossa relação com as obras ${ }^{8}$ e que permite filologicamente falar de sua "coerência", de que derivam conceitos e práticas restitutivos dos textos como os de lectio difficilior ${ }^{9} \mathrm{e}$

7 Afirma Segismundo Spina que há textos "genuínos" e textos "autênticos", ambos chancelados pelo autor. A diferença entre ambos estaria no fato de que um texto pode ser publicado várias vezes sob autorização do autor, mas que de uma edição à seguinte pode ser modificado parcialmente pelo agenciamento mesmo da instância autoral. Ou seja, encontramo-nos diante de um conjunto de edições que atestam o estatuto fluido da "obra", cuja variação pode ser verificada pela comparação entre edições, que nada mais são do que estados de uma "obra" in fieri. Segismundo Spina chamará, por fim, texto "genuíno" àquele que representa a interrupção do processo de remanejamento a que foi submetido o "primeiro texto" e os demais que a ele se seguiram, sendo as etapas textuais que conduzem a esse fim último designadas pelo apelativo "autênticas": "Um texto pode ser legítimo, autêntico, mas não genuíno. Suponhamos a primeira edição de uma obra: ela é autêntica, legítima (isto é, não é falsa) porque saiu em vida do autor e foi supervisionada por ele. Acontece que nem sempre a primeira edição corresponde ao desejo do autor, que nela encontra falhas e coisas que não condizem com seu espírito. Assim, uma edição ne varietur é uma edição definitiva, saída conforme os desejos do autor; talvez seja ela a quarta edição. Esta quarta edição é genuína, mas as três primeiras não o são, embora sejam autênticas, legítimas". (SPINA, Segismundo. Op. cit., 1994, p. 27).

8 Ibidem, p. 124.

9 O critério da lectio difficilior baseia-se na presunção de que os copistas, ao efetuarem a cópia, produzem trivializações de passagens de difícil entendimento, conquanto não se explique, nos manuais que ensinam o neolachmannismo entre nós, como se coadunam os critérios da lectio difficilior e do scriba doctus. Se há este último, o que o impede de rumar contra a trivialização? Dessa óbvia contradição nada falam SPINA, Segismundo. Op. cit., 1994, p. 105 e seguintes; AZEVEDO FILHO, Leodegário A. de. Iniciação em Crítica Textual. Rio de Janeiro/São Paulo: Presença/Edusp, 1987; CAMBRAIA, César Nardelli. Introdução à Crítica Textual. São Paulo: Martins Fontes, 2005, p. 154. 
de usus scribendi ${ }^{10}$. Uma proposta filológica que visasse a fissurar, "quando pertinente", o paradigma filológico centrado na figura do autor, deveria esforçar-se por compreender a cadeia das recepções, que é muita vez cadeia irregular e descontínua de emergência da "obra" na história e que implica atualizações mais ou menos parciais, no presente da apropriação, de enunciados pretéritos, importante para o conhecimento das relações históricas entre a "obra" e seus auditórios. O devir da "obra", sobretudo em culturas dependentes em grande medida da oralidade e da manuscritura, pode e às vezes deve ser entendido como uma continuidade ou descontinuidade de qualquer modo heterogênea e que deve abolir a crença em uma teleologia filológica da decrepitude das tradições e de um complementar e sadio resgate das origens pelo filólogo. Embora não abarque totalmente a noção de emergência e de descontinuidade que aqui significamos, Paul Zumthor acena para ela ao tratar da relação entre performance e tradição:

Besides, at the heart of the tradition which it cannot help but be referred to, oral poetic performance stands out like a discontinuity in the continuous - "historical" fragmentation whose effect seems all the more apparent as the tradition gets older and more explicit and embraces elements that are better diversified. So, in the economy of the cycle literatures (the legend, epic, tale, song cycles), we find virtual superunities whose property is to never be realized as a whole - a vast treasure house which the narrator, the singer, or the oral performer seems to draw from according to his own desires at each performance. ${ }^{11}$

A "obra", por razão de seu devir, tem um caráter protéico e seu polimorfismo insta-nos a que a compreendamos. Como bem o diz Henri Zerner, "a história [da cadeia de recepções] organiza-se num sistema de diferenças e de descontinuidades que articulam a duração"12.

O que aqui se pergunta é se há necessidade de uma filologia da re-fundação, cujo fim último seria o achado da pedra fundamental da urbe eterna, que é a obra emanada da mens auctoris, re-fundação essa alicerçada na pedra filosofal de uma filologia que se ajuíza capaz de eliminar todo "azinhavre", que é a história, e a tudo transformar em ouro. A filologia da

${ }^{10} \mathrm{O}$ usus scribendi pode ser definido como o estabelecimento pelo crítico do que se convencionou denominar "estilo", seja aquele referente a um autor ou a uma época. No primeiro caso, supõe a estabilidade da categoria variavelmente histórica de "autoria", tal como passou a ser compreendida a partir do Romantismo, e sua simultânea trans-historicização, pelo método, a outros tempos e lugares. Para uma crítica do que se convencionou denominar "estilo de época", como, por exemplo, "Barroco", remetemos ao excelente ensaio de HANSEN, João Adolfo. "Barroco, neobarroco e outras ruínas". In: Floema: Caderno de Teoria e História Literária, Vitória da Conquista, 2 A, 2006, pp. 15-84.

11 ZUMTHOR, Paul. "The Text and the Voice". In: New Literary History, vol.16, (1), 1984, pp. 67-92 [p. 77].

12 ZERNER, Henri. “A Arte”. In: LE GOFF, Jacques \& NORA, Pierre (Ed.). História: Novas abordagens. São Paulo: Livraria Francisco Alves, 1988, pp. 144-159 [p. 154]. 
re-fundação basear-se-ia em uma operação de caráter dedutivo, em que, à unidade historicamente invariável da instância de expressão ${ }^{13}$, se produz um seu correlato no campo dos discursos. É o que já dizia Michel de Certeau, ao alertar-nos para a interpretatio fundada na quimera da identidade entre homem, obra e pensamento, que se desejava evitar:

Deseja-se ultrapassar a concepção individualista que recorta e reúne escritos segundo sua "pertença" a um mesmo "autor", que, então, fornece à biografia o poder de definir uma unidade ideológica, e supõe que a um homem corresponda um pensamento (como a arquitetura interpretativa que repete o mesmo singular nos três andares do plano clássico: o Homem, a obra, o pensamento). ${ }^{14}$

Essa primeira condição de realização da crítica filológica neolachmanniana entre nós vem sempre associada a uma crença em totalidades mentais históricas, que complementam a referida unidade anterior, e que, embora não se nomeiem mais como Weltanschauung e seus correlatos, ainda implicam um reducionismo interpretativo e uma circularidade de leitura, a que Marc Bloch deu o nome de fisiognomonia histórica ${ }^{15}$ :

Essas unidades de medida se referem ao que Lévi-Strauss chamará de a sociedade pensada em oposição à sociedade vivida. Elas tendem a fazer ressaltar dos conjuntos "sancionados" por uma época, quer dizer das coerências recebidas, implicadas pelo "percebido" ou pelo "pensado" de um tempo, sistemas culturais suscetíveis de fundar uma periodização ou uma diferenciação dos tempos. [...] Elas ocupam o lugar de uma "alma coletiva" e permanecem como vestígio de um ontologismo. Na impossibilidade de poder ser realmente controlável, esse sub-solo é extensível; pode se estender ou contrair à vontade; tem a amplitude dos fenômenos a "compreender". De fato, mais do que ser um instrumento de análise, representa

13 Paul Zumthor, ao discorrer sobre a emersão gradual da literatura como campo discursivo autonomizado, declara: "Literatura e sua família lexical davam assim, pouco antes de 1800 , forma e rosto a um conjunto de representações e tendências errantes - e tardiamente associadas - na consciência européia desde quatro, cinco ou seis séculos: pré-história confusa, que lentamente tinha emergido das zonas do não-dito. Uma noção nova se constituía, no seio das tradições existentes, pela imposição de vários esquemas de pensamento, funcionando de maneira oculta como parâmetros críticos: idéia de um 'sujeito' enunciador autônomo [grifo nosso], da possibilidade de uma apreensão do outro, a concepção de um 'objeto' reificado, o primado atribuído à referencialidade da linguagem e simultaneamente à ficção; pressuposição de alguma sobretemporalidade de certo tipo de discurso, socialmente transcendente, suspenso num espaço vazio e constituindo por ele mesmo uma Ordem." (ZUMTHOR, Paul. A Letra e a Voz: A literatura medieval. São Paulo: Companhia das Letras, 1993, pp. 278-279).

${ }^{14}$ CERTEAU, Michel. Op. cit., p 39.

${ }^{15}$ BLOCH, Marc. Apologia da História ou o Ofício do Historiador. Rio de Janeiro: Jorge Zahar, 2001. 
a necessidade que tem dele o historiador; significa uma necessidade de operação científica, e não uma realidade apreensível em seu objeto. ${ }^{16}$

Pode-se nesse momento reciclar uma proposição de Roger Chartier concernente ao sujeito e dizer que o autor foi sempre compreendido pela filologia da re-fundação como indivíduo na "liberdade suposta de seu eu próprio e separado"17 , mas não como"construído pelas configurações (discursivas e sociais) que determinam suas definições históricas"18, o que poderia simplesmente implicar, levando-se em consideração essa última possibilidade e hipótese que ora acatamos, do ponto de vista das práticas e das categorias que permitem sua intelecção, definições de "autoria" entre si irredutíveis. Toda filologia, por conseguinte, que se quisesse histórica, e não há filologia que pudesse não o ser sendo filológica, deveria encenar a diferença ou a alteridade que subjaz sob a constância das palavras. A filologia da re-fundação, no entanto, encontra apenas na in-variação a-histórica da categoria "autoria" e na correlata de "genuinidade", que é corolário daquela, as condições de produção de seu discurso crítico, pois ambas lhe permitem estabelecer uma relação imaginada com a realidade "desaparecida a ser resgatada e compreendida" em sua parole sempre inaugural - ou seja, uma personalidade alheia que urge capturar ${ }^{19}$. A operação filológica visaria assim a asseverar como verdadeira a relação que estabelece entre a fixação do texto e a escritura autoral, restituindo textualmente o recém-nascido a partir de uma população de mortos, que são os testemunhos apógrafos constituintes da tradição, e, ao mesmo tempo, visaria à produção da ilusão da presentificação da "realidade referencial" que é o autor por meio do estabelecimento do seu dictum, ao fazer falar na primeira pessoa o que só pode ser conjugado na terceira. Essa filologia, assim, é uma heterologia, como a define Michel de Certeau, pois se construiu "em função da separação entre o saber que contém o discurso e o corpo mudo que o sustenta" ${ }^{20}$, corpo que a crítica filológica propõe ressuscitar em sua voz: fala-se sempre em nome do autor e de seus interesses. Parece querer fazer cumprir o vínculo que desde os gregos se supõe haver entre poesia e perenidade: mesmo que a filologia não possa garantir a athanasía individual ${ }^{21}$, assegura pelo menos a perpetuação das "palavras do poeta" e, por conseguinte, uma certa "memória" sua. Mas

${ }^{16}$ CERTEAU, Michel. Op. cit., p. 39.

17 ZERNER, Henri. Op. cit., 1988, p. 148.

18 Ibidem.

19 PICCHIO, Luciana Stegagno. A Lição do Texto. Filologia e Literatura: I - Idade Média. Lisboa: Edições 70, 1979, pp. 209-235 [p. 214].

20 CERTEAU, Michel. A Escrita da História. São Paulo: Forense Universitária, 2002, p. 15.

21 ARENDT, Hannah. "O conceito de História - Antigo e moderno". In: Entre o Passado e o Futuro. São Paulo: Perspectiva, 2009, pp. 69-126 [p. 76]. 
como o faz? Pode-se dizer aqui que a crítica textual neolachmanniana substitui o sujeito de uma operação histórica pelo sujeito de uma operação filológica (historiográfica).

Os esforços do filólogo, em seu afã de constituir o texto crítico, não tinham outro objetivo que o de "libertar uma obra de tudo o que a impedia de atingir-nos em sua integridade"22, mas a consecução desse fim partia de uma idéia de "integridade" motivada por preconceitos de base romântica que produziam uma equivalência entre "integridade" e "genuinidade". Esforço para articular no presente a personificação de uma ausência pelo recurso à "prosopopéia", embora a filologia da re-fundação não se queira retórica.

O método, enquanto esquema conceitual, parece limitar a cognição individual com tamanho rigor, que acaba por fazer crer aos seus praticantes que institui um discurso crítico "de acordo com a ordem natural das coisas", o que torna o pensável dependente do pensado e do instituído. É como se a filologia de base romântica, originada no século XIX, fortemente assentada em instituições de saber, como já o demonstraram, para o âmbito dos estudos filológicos na França e na Espanha, respectivamente Hans Ulrich Gumbrecht ${ }^{23}$ e Joan Ramon Resina ${ }^{24}$, houvesse se tornado a lei de um grupo, o dos filólogos, e a lei de uma pesquisa "científica". "A instituição não dá apenas uma estabilidade social a uma 'doutrina'. Ela a torna possível [...]"25, é o que nos ensina Michel de Certeau. Mary Douglas, em seu conhecido estudo intitulado Como as Instituições Pensam, ao discorrer sobre a relação entre produção historiográfica e locus institucional e sobre como este acaba por circunscrever aquela, assevera:

As instituições criam lugares sombreados nos quais nada pode ser visto e nenhuma pergunta ser feita. Elas fazem com que outras áreas exibam detalhes muito bem discriminados, minuciosamente examinados e ordenados. [...] Observar essas práticas estabelecerem princípios seletivos que iluminam certos tipos de acontecimentos e obscurecerem outros significa inspecionar a ordem social agindo sobre as mentes individuais. ${ }^{26}$

Mas como pôde ela, a "doutrina" neolachmanniana de que ora se fala, entre nós, ganhar a força inercial que ainda a mantém, não infensa, mas bem estabelecida em baluartes que a atualizam - tornam-na "atual" - ao aplicá-la invariavelmente a incontáveis "objetos"?

22 STAROBINSKI, Jean. "A literatura: O texto e o seu intérprete". In: LE GOFF, Jacques \& NORA, Pierre (Ed.). História: Novas abordagens. São Paulo: Livraria Francisco Alves, 1988, pp. 132-143 [p. 133].

${ }^{23}$ GUMBRECHT, Hans Ulrich. "Un Souffle d'Allemagne Ayant Passé: Friedrich Diez, Gaston Paris, and the Genesis of National Philologies". Romance Philology, Berkeley, 40, 1986, pp. 1-37.

${ }^{24}$ RESINA, Joan Ramon. "Hispanismo e Estado". In: Floema: Caderno de Teoria e História Literária, Vitória da Conquista, Especial 3 A, 2007, pp. 99-147.

25 CERTEAU, Michel de. Op. cit., 2002, p. 70.

${ }^{26}$ DOUGLAS, Mary. Como as Instituições Pensam. São Paulo: Edusp, 1998, p. 75. 
Inércia de uma reflexão teórica que se reflete na reificação de procedimentos metodológicos presentes entre os manuais que instruem os neófitos? Cremos que seja essa a explicação e não uma possível doutrina que equivalesse a uma natura naturalis disciplinar. Mary Douglas, ao sintetizar o que Ludwik Fleck definia como "coletividade de pensamento", insistiu simultaneamente na persistência da traditio e em seu caráter hierarquizado - elites pensantes no centro e epígonos nas bordas, o que torna a periferia necessariamente mais inerte -, e, ao citar aqui Fleck, fazemo-lo compreendendo "comunidade de pensamento" como traditio disciplinar, e não como uma "mente individual" hipostasiada, interessando-nos, sobretudo, o problema da hierarquia e o que implica em termos de "economia de discursividade", de distribuição de "capital discursivo" e de "periferia inerte":

Admitia [Fleck] que as comunidades de pensamento coletivo variassem de acordo com sua persistência ao longo do tempo, das formações mais transitórias e acidentais às formações mais estáveis. Julgava o pensamento das formações estáveis mais disciplinado e uniforme, a exemplo do que ocorria nas associações, sindicatos e igrejas. [...] Uma elite interna, de iniciados hierarquizados, existe no centro e a massa se localiza nas bordas. $O$ centro é o ponto que põe tudo em movimento. As bordas adotam suas idéias em um sentido literal e inquestionável; a ossificação ocorre exatamente aí. ${ }^{27}$

\section{(II.3)}

Não se reconhecia e muita vez ainda não se reconhece àquilo que se edita o direito de alteridade, de ser diferente, e é por razão dessa possibilidade de diferença constitutiva do objeto em termos históricos que Jean Starobinski afirma: "Antes de toda explicação, antes de toda interpretação compreensiva, deve ser o objeto reconhecido em sua singularidade ${ }^{\prime \prime 2}$. É preciso dizer que o trabalho de restituição textual, norteado a priori por um conjunto de categorias críticas historicamente situadas e que não são relativizadas pela maior parte dos filólogos brasileiros, implica a inscrição de um sentido único, ajuizado como próprio para a tradição a ser editada, e que se produz por subtração. Frente a tradições em que abundam as variantes adiáforas e as variantes de autor, e apesar das lições de historiadores da literatura, como Paul Zumthor, que nos demonstraram o caráter instável e fluido da textualidade "medieval"29, o editor crítico, sendo interpres, transaciona

27 Ibidem, p. 27.

${ }^{28}$ STAROBINSKI, Jean. Op. cit., 1988, p. 133.

29 ZUMTHOR, Paul. Essaide poétique médiévale. Paris: Éditions du Seuil, 1972; ZUMTHOR, Paul."Intertextualité et mouvance". In: Littérature, Paris, vol. 41, 1981, pp. 8-16; ZUMTHOR, Paul. Op. cit., 1993; ZUMTHOR, Paul. "A poesia e o corpo". In: Escritura e Nomadismo. São Paulo: Ateliê Editorial, 2005. 
o objeto de estudo com vistas a entregá-lo ao público que lhe é coetâneo, transcodificando-o, sendo que a trans-codificação implica que uma poética e as práticas que se lhe associam são substituídas por uma outra, extemporânea do que se edita, podendo-se concluir que coube ao filólogo: "anular o efeito da distância, ele transporta a obra da margem distante de que é originária para a margem onde nasce o discurso interpretativo, em sua relação atual com seus destinatários" ${ }^{\prime 30}$. Os neolachmannianos deveriam aprender com Paul Zumthor que a água das cascatas é sempre igual a si mesma e sempre diferente, e só se torna absolutamente igual a si mesma ao fluir pelo ducto do método crítico que se lhe impõe e que lhe reduz, segundo o pensam alguns filólogos, sua entropia. Quanto a esta crença na redução da entropia, têm razão, pois a água, ao passar pelo fino ducto da crítica filológica, ne bouge pas ${ }^{31}$. A filologia dos neolachmannianos constituiu como seu objeto a lexis, e passou a restituí-la por meio de uma poiesis, pondo de lado, entretanto, a praxis que poderia e deveria explicar o estado da lexis antes da intervenção crítica. É como se a lexis, objeto da filologia, pudesse ser matéria da história e da recordação, e ser, ao mesmo tempo, objeto de um total desembodiment; ou, antes, é como se esse desembodiment fosse condição de a lexis ser o objeto da atividade filológica em algumas de suas modalidades constituídas. Como bem o disse Carlo Ginzburg:

O seu objeto [da Crítica Textual], de fato, constitui-se através de uma drástica seleção - destinada a se reduzir ulteriormente - dos elementos pertinentes. Esse acontecimento interno da disciplina foi escondido por duas cesuras históricas decisivas: a invenção da escrita e a da imprensa. Como se sabe, a crítica textual nasceu depois da primeira (quando decidiu-se transcrever os poemas homéricos) e consolidou-se depois da segunda (quando as primeiras e freqüentes apressadas edições dos clássicos foram substituídas por edições mais confiáveis). Inicialmente, foram considerados não pertinentes ao texto os elementos ligados à oralidade e à gestualidade; depois, também os elementos ligados ao caráter físico da escrita. $\mathrm{O}$ resultado dessa dupla operação foi a progressiva desmaterialização do texto, continuamente depurado de todas as referências sensíveis [...]. ${ }^{32}$

30 STAROBINSKI, Jean. Op. cit., p. 141.

31 Remo Bodei, ao falar da experiência do jovem Hegel frente aos Alpes, diz que ele não sentiu nenhuma comoção frente à imobilidade das montanhas, mas que sua disposição mental "heraclitiana" o fez comover-se diante da mobilidade fluida das águas, sempre iguais e sempre diferentes (BODEI, Remo. A História Tem um Sentido? Bauru: Edusc, 2001, p. 52).

32 GINZBURG, Carlo. "Sinais: Raízes de um paradigma indiciário". In: Mitos, Emblemas e Sinais: Morfologia e história. São Paulo: Companhia das Letras, 1989, pp. 143-179 [p. 157]. 
Para a compreensão da poética "medieval", por exemplo, faz-se necessário relacionar o texto, que "se fait dans le temps"33, com o espaço, não aquele da inscrição, mas aquele em que no passado a voz decorosa a cada gênero o fazia soar e funcionar sob condições em que prevaleciam os valores dramáticos: “Le cas le plus net est celui du 'jeu' liturgique, qui s'inscrit dans un lieu architectural; mais, aussi bien, la chanson de geste se situe sur la place ou dans la cour où l'on interpelle les badauds; le roman, dans la chambre des dames; le jeu dramatique, en un lieu de la ville." ${ }^{34}$ Ainda segundo Paul Zumthor, ao componente propriamente vocal, uniam-se o som e o gesto, e mesmo quando se passou a se inscrever o texto sobre um suporte, “il n'en implique pas moins par définition les tons, les accents, les rhythmes, toute la richesse d'une phonétique et d'une prosodie"35, já que a leitura enquanto fenômeno puramente ocular só há de se consolidar em fins do que se convencionou designar como Baixa Idade Média. Deriva do exposto que o enunciado não se separa da enunciação e esta "implique des facteurs personnels ou situationnels partiellement étrangers au système linguistique. Geste et voix constituent une certaine manière, pour le texte, d'être présent" ${ }^{\text {"36 }}$ Mas se a vocalidade é constitutiva da poesia "medieval" e se o texto não se refere, sobretudo, ao espaço da escritura, mas ao tempo da enunciação, ele será para os homens da sociedade "medieval" um objeto auditivo e, por conseguinte, fluido e movente ${ }^{37}$.

É preciso discernir entre o papel da escritura enquanto comunicação e, por outro lado, enquanto fenômeno de preservação do que fora veiculado pela voz.

Alguns estudiosos, a partir dos trabalhos de Paul Zumthor, têm insistido na necessidade de se empreender uma pesquisa que leve em consideração tanto o texto quanto a música das cantigas trovadorescas e dos demais gêneros poéticos que então eram performados, e que tente, por meio de uma pesquisa de cunho "arqueológico" sobre as práticas performativas da sociedade do Ocidente "medieval", pôr em cena, nos dias de hoje, a performance como uma hipótese verossímil de trabalho acadêmico e artístico ${ }^{38}$. O que há a objetar em

33 ZUMTHOR, Paul. Op. cit., 1972, p. 38.

34 Idem, ibidem.

35 Idem, p. 40.

36 Idem, p. 41.

37 Paul Zumthor, ao discorrer sobre a relação que o texto poético podia manter com uma escritura, enfatiza que o seu repositório primeiro era, no entanto, o corpo e a memória, caracterizada esta por sua imperfeita reiterabilidade, o que, de qualquer forma, parece convergir com os procedimentos da composição em performance: "There is no doubt that poetic voice carries the imprint of some 'arche-writing', but this imprinted trace is inscribed there in a specific manner, since voiced discourse given aloud hás its roots more clearly in the human body and in other narrowly defined areas and lends itself better to the inflections of memory" (ZUMTHOR, Paul. Op. cit., 1984, p. 69).

38 O'NEILL, Terry \& PADEN JR., William. "Toward the Performance of Troubadour Poetry: Speaker and Voice in Peire Vidal". In: Educational Theatre Journal, vol. 30 (4), 1978, pp. 482-494. 
algumas dessas propostas, contudo, é que, ao proporem, para os poemas cujas notações musicais foram perdidas ou nunca inscritas, uma forma contemporânea de performance em que a ausência do elemento musical seria suprida por uma teatralidade que não reduziria a canso ao seu elemento puramente textual ${ }^{39}$, esquecem-se de que o teatro, como o disse Paul Zumthor, sempre foi a forma acabada de realização da poesia "medieval", e a teatralidade, por conseguinte, não pode ser elemento substitutivo para a música, porque não pode suprir por si só um componente da arte poética de então.

Esse modo performatizado de insuflar alguma vida nos poemas que o passado nos legou tem de ser por necessidade verossímil, pois não poderá equivaler de forma plena às performances coetâneas do público primeiro dos poemas, o que torna evidente, por exemplo, as simples querelas presentes sobre a interpretação das melodias e dos próprios textos.

Contrariamente ao modo de decodificação da mensagem poética que por muito tempo predominou nos estudos literários do século XX e em que o conhecimento que se tinha do autor jogou um papel de primeira importância na interpretatio, o auditório que constituía a recepção primeira dos textos poéticos "medievais" tinha diante de si, quando da execução da performance, um locutor: "Moins qu'un auteur, celui qui entend le texte voit un locuteur, dont il sait à l'évidence ce qu'il est; et ce locuteur emploie un code où la relation qui les lie se trouve engagée [...] $]^{\prime 40}$. Paul Zumthor, em outro livro, fala-nos que a subsistência da marca escrita não anula a validade da assunção de que há uma imanente vocalidade nos textos "medievais", que pode ser percebida pelos inúmeros índices de oralidade ${ }^{41}$ neles presentes. Afirma, outrossim, que, se os textos fossem metaforizados como "espelho", seria preciso, para uma compreensiva análise histórico-filológica dos mesmos, raspar um pouco do estanho sob a vista para ler o que está por baixo do que se apresenta aos olhos:

este resíduo: o múltiplo sem origem unificadora nem fim totalizante, a discórdia de que fala Michel Serres e cujo conhecimento pertence ao ouvido. É aí, e aí somente, que se situa para nós a oralidade de nossa "literatura medieval": vocalidade-resíduo de nossas filologias, indócil a nossos sistemas de conceitualização.

39 Idem, p. 483 (By substituting theatre for music we accommodate ourselves to the irreparable loss of so many melodies while recreating the tension between two media which gave this art its expressive power).

40 ZUMTHOR, Paul. Op. cit., 1972, p. 42.

41 Define-se da seguinte maneira "índice de oralidade": "Por 'índice de oralidade' entendo tudo o que, no interior de um texto, informa-nos sobre a intervenção da voz humana em sua publicação - quer dizer, na mutação pela qual o texto passou, uma ou mais vezes, de um estado virtual à atualidade e existiu na atenção e na memória de certo número de indivíduos." (ZUMTHOR, Paul. Op. cit., 1993, p. 35). 
A vocalidade-resíduo de nossas filologias é varrida para baixo da estanhada superfície do texto restituído, em que se pode perceber, se se olhar bem, o reflexo do editor e de suas idiossincrasias.

Acresce-se aos índices de oralidade o que se define mais à frente como "presunção de oralidade", ou seja, quando, a par dos índices dispersos pela tessitura do poema, verifica-se, na tradição manuscrita, uma pluralidade de variantes que atestam "uma margem de manobra propícia às iniciativas dos recitadores, isto é, ao desdobramento de sua arte

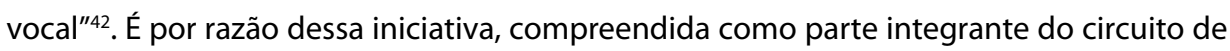
produção, circulação e recepção dos poemas, que Paul Zumthor concebe como mal formulada a questão posta para si mesmos por tantos filólogos no passado: "que distinção fazer entre autor e intérprete?" ${ }^{\prime 3}$ Outros estudiosos da poesia trovadoresca, mais recentemente, demonstraram, para o âmbito da langue d'oil, como as formas poéticas aparentemente mais estáveis e fechadas continham seções em que se podia mover o texto: embora a primeira estrofe da chanson dos trouvères e o envoi não fossem movidos na quase que absoluta maioria dos casos, as estrofes entre eles, mesmo no caso de composições em coblas doblas, que dificultavam por sua peculiar estrutura o remaniement, eram geralmente objeto da movência ${ }^{44}$.

O que sabemos, com certeza, a partir dos progressos no campo da história do livro e da leitura na Europa é que a escritura, como bem o disse Paul Zumthor, "funciona em uma zona de oralidade", o que tornam patente os inventários das bibliotecas monásticas e reais da dita "Baixa Idade Média", em que o número de volumes por acervo é bastante pequeno e em que não constava ou constava de forma numericamente reduzida o repertório hoje canônico da poesia vernacular "medieval":

As bibliotecas continuavam numa pobreza surpreendente. Por volta de 1080, a de Toul, renomada, contava com 270 volumes; a de Michelsberg, em 1120, possuía 242, com um livro árabe e dois livros gregos de matemática; a de Corbie, por volta de 1200, tinha 342; a de Durham, uma das maiores da Europa, à mesma época, 546; a da Sorbonne, por volta de 1250, mil. [...] Em sua mui bela biblioteca, o rei Charles V chegou a reunir mil; os duques da Borgonha, novecentos. ${ }^{45}$

42 Idem, p. 43.

43 Idem, p. 70.

44 STEINLE, Eric M. “The Protean Voice: Textual Integrity and Poetic Structure in the Trouvère Lyric, Using an Example by Gace Brulé". In: Pacific Coast Philology, vol. 20 (1/2), 1985, pp. 89-95.

${ }^{45}$ Idem, p. 98. 
Pequena também era a "tiragem" de um poema que alcançara grande sucesso, como é o caso do Roman de la Rose, cujos exemplares restantes (cerca de trezentos) foram produzidos em uma duração lata - gênero esse que se associa normalmente à leitura. O que dizer dos poemas pertencentes a gêneros associados à voz? Quando e por que razões se passou a inscrevê-los? A fluidez das tradições manuscritas, mesmo para poemas que pertencem a gêneros não associados tradicionalmente à performance e a tudo o que ela implica em termos de textualização, parece atestar que "o copista mais discreto continua 'intérprete', em todos os aspectos desse termo, inclusive glosador"46. A fluidez que permeia muitas tradições faz-se presente até bem entrada a "Idade Moderna", como o atesta a poesia de língua portuguesa dos séculos XVI e XVII. Em tradições em que abundam as variantes adiáforas e que são constituídas de manuscritos apógrafos, como o é a de Gregório de Matos Guerra, já no século XVII, não há como determinar quais lições são devidas aos "copistas" ou àquelas muitas bocas que fizeram, na colônia desprovida de imprensa, circular os poemas atribuídos à musa satírica. É preciso antes pensar que, em pleno século XVII, os que inscrevem os poemas em folha volante nada mais fazem do que tornar inerte parte de uma voz e congelar a modulação que torna o código lingüístico joguete da matéria sonora. Não é a espessura da voz o que se visa a fazer soar por meio do bilingüismo de muitos poemas satíricos do século XVII, voz essa, "selvagem", que, no caso da América portuguesa, presentifica o negro da terra, a nobreza da terra e sua algaravia ininteligível, o que intensifica, mais do que qualquer sentido objetivo possível, o efeito do risível próprio da sátira pela evidência da falta de humanidade evidente na algaravia? E como descrer, diante dos sonetos gregorianos, que uma forma como o soneto pudesse, em pleno século XVII, ser parasitada pela voz?: "A linha feminina é carimá,/ muqueca, petitinga, caruru,/ mingau de puba, vinho de caju,/ pisado num pilão de pirajá." Não é o sentido poético profundo, que o som desses vocábulos faz reverberar, o que levou tantos ouvintes, fossem eles mais ou menos letrados, a intervir nessa massa sonora e a modulá-la segundo um gosto fundado no ouvido, para além de qualquer atenção prestada ao rigor semântico que para nós é tão importante nos dias de hoje? Não foi esse gosto pela modulação sonora que gerou tantas variantes, constituídas de elementos textuais que mudam de lugar, que migram no interior de versos, de estrofes, de poemas e entre poemas? E não é o apreço pela oralidade o que faz com que se valha do bilingüismo de certos poemas como uma estratégia expressiva em que predominam a adição e a agregação de termos, por seus valores étnico-fônicos, em detrimento de uma preocupação lógico-sintagmática, como é o caso de Há coisa como ver um paiaiá ou ainda Um rolim de Monai, bonzo, bramá, na tradi-

46 ZUMTHOR, Paul. Op. cit., p. 1994, p. 103. 
ção de Gregório de Matos Guerra? Não se trataria aqui do que Paul Zumthor denominou mouvance? E não seria essa mesma algaravia, em sua funcionalidade poética - matéria por metonímia de muitos poemas -, pronunciada alegremente por aqueles que desejavam vergastar os brios da nobreza da terra, o que induz os que recitam os poemas, no calor da récita, a torná-la ainda mais ininteligível? - o que reduz muita vez o texto que nos chegou a uma massa sonora disjunta e que revela o predomínio do significante pelo império da enunciação performativa, ou seja, uma motivação sinestésica somente bem acabada por meio de uma "encenação". Não há como descrer que, no caso da América portuguesa do século XVII, poemas pudessem também ser lidos, não apenas em voz alta, mas silenciosamente, no espaço privado, embora por uma minoria, o que torna complexa a situação de partilha social da poesia nos Seiscentos, em que, a par de uma comunicação mediatizada pelo intérprete, há aquela diferida pela leitura.

\section{(II.4)}

Rupert T. Pickens, quando preparou a edição sinóptica das cantigas de Jaufré Rudel, deparou-se com o uso do verbo "mover", empregado para designar a atividade do trovador ao compor suas cantigas, assim como para caracterizar o cantar do rouxinol. O verbo provençal "mover" subsume um conjunto de práticas poéticas que autorizam o remanejamento constante de uma tradição textual herdada. Assim como o rouxinol move o seu canto, assim o poeta e seu auditório movem qualquer cantiga composta ${ }^{47}$. A "mouvance" zumthoriana encontra, por conseguinte, sua origem no cerne da prática poética "mediévica", que pode ser devidamente substanciada no verbo provençal "mover". Assim como Pickens, Gregory Nagy, em seu já clássico Poetry as Performance, associa o conceito zumthoriano de "mouvance" ao verbo em langue d'oc "mover" e afirma que em poesias de Jaufré Rudel essa associação se evidencia por meio da seguinte prática, que não reduz, no entanto, o "mover" a si: embora o intermediário entre o poeta e seu auditório não esteja autorizado a "mover" a cantiga até ela ser entregue aos destinatários, estes últimos não apenas estão autorizados a fazê-lo, mas se espera inclusive que o façam: "e faran hi/quas que don most chans gensara" (Song VII, version I); "e faran y/calsque motz que hom chantara" (Song VI, version lb) ${ }^{48}$. Depreende-se do exposto que as inovações e as interpolações, mesmo quando não autorais, podem portar autoridade, porque legítimos produtos históricos de práticas poéticas que caíram em desuso. A busca pela unidade - hodiernamente, e

47 PICKENS, Rupert T. The Songs of Jaufre Rudel. Toronto: Pontifical Institute of Medieval Studies, 1978, p. 42.

48 NAGY, Gregory. Poetry as Performance: Homer and Beyond. Cambridge: Cambridge University Press, 1996, p. 14. 
apenas hodiernamente - da obra por nós ajuizada "corrupta", fixada como o objeto da crítica textual, pode falsear, por conseguinte, a natureza protéica da tradição, compreendida como múltipla e instável por seu auditório coevo. Redundaria, por conseguinte, falseada filológica - e historicamente - uma representação da tradição de Jaudré Rudel, que a propusesse una, fazendo derivar todos os testemunhos que nos chegaram de um arquétipo ou original, ou edições que repusessem em circulação os textos de somente um testemunho considerado optimus, ou que adotassem a prática da conflation para gerar, a partir dos testemunhos, um texto compósito, que não se identificaria com nenhum dos testemunhos. $A$ primeira das práticas editoriais é característica dos discípulos de Joseph Bédier, a segunda, daqueles que aderiram à restitutio textus das escolas alemã e italiana de Filologia.

A proposta bedierista de edição equaliza testemunho à obra, enquanto a segunda constitui um texto que nunca foi objeto de recepção no passado, a não ser de modo muito hipotético, pois se pode aventar que o texto reconstituído equivalha ao arquétipo ou original, conquanto não se perguntem os editores que assim se propõem editar os textos passados se era legítimo afirmar a existência de um arquétipo ou original para a tradição que está sendo editada, de que só restariam cópias eivadas de erros. Não há como descrer de que o poeta ele próprio participasse do remanejamento, autorizando novas versões e múltiplas variantes a cada nova publicação performada ${ }^{49}$.

Pode-se dizer que a correlação entre Filologia e "restauração, intelecção e explicação dos textos", tal como proposta por Segismundo Spina ${ }^{50}$, a partir de uma longa tradição filológica, que remonta a tempos passados, de modo paradoxal elidiu a possibilidade crítica de criticar-se a própria correlação, pois se é pertinente compreender a filologia como ars de intelecção e explicação de textos, por outro não é apropriado dizer que cabe a ela "restaurar" os textos, a não ser que se entenda a "restauração" como procedimento que pode inclusive elidir a própria restitutio textus, que é aquilo que "restauração" significa em textos filológicos spinianos ${ }^{51}$. Restaurar a tradição de Jaufré Rudel significaria repor em

49 Esse parece ser o juízo de Luciana Stegagno Picchio atinente às variantes do soneto "Alma minha gentil" (STEGAGNO PICCHIO, Luciana. "Camões lírico: Variantes de tradição e variantes de autor. Exemplos para o estudo da movência em textos camonianos". In: Actas da V Reunião Internacional de Camonistas: São Paulo, FFLCH, 1987, pp. 285-309).

50 SPINA, Segismundo. Op. cit., p. 67.

${ }^{51}$ O mesmo problema se apresenta no manual de César Nardelli Cambraia, quando se declara: "Considerando que, após se ter restituído a forma genuína [grifo nosso] de um texto escrito, ele é, via de regra, publicado novamente, contribui-se também, assim, para a transmissão e preservação desse patrimônio: colabora-se para a transmissão dos textos, porque, ao se publicar um texto, este torna-se novamente acessível ao público leitor; e contribui-se para a sua preservação, porque se assegura sua subsistência através de registro em novos e modernos suportes materiais, que aumentarão sua longevidade" (Op. cit., pp. 19-20). 
circulação todas as variantes textuais presentes nos diversos testemunhos e que foram objeto de recepção e remanejamento pelos auditórios coevos do poeta, já que "restauração", dessa maneira, seria dar ao público contemporâneo do editor condições para que se desse, filológica e historicamente, a promoção da intelecção e explicação da tradição de que as variantes textuais participam e em que estão subsumidas. Se é certo dizer, com Celso Cunha, que "Edição pressupõe interpretação"52, esta deve dizer respeito, antes de incidir sobre os textos, à conformação histórica da própria tradição a partir do entendimento das práticas poéticas e letradas que lhe deram origem e que são marcadas por uma dada historicidade, historicidade essa que não só pode mas deve prescindir da crença, inclusive denegando-a, disseminada entre os filólogos, de que toda fixação de texto visa àquele texto "que tenha maiores probabilidades de se avizinhar do pensar e do sentir do autor no momento da eclosão artística"53. A palavra "eclosão", por seu turno, remete a uma idéia ex nihilo de origem dos textos literários, que evidencia sua matriz romântica.

\section{(II.5)}

A redução do ruído, ruído este que separa a tradição do público coetâneo do editor crítico, não deve se dar por uma anulação do efeito de distância que equivalha à eliminação de tudo aquilo que, na tradição, por ser "outro", demande do público a que a edição se dirige esforço para o reconhecimento e conhecimento dessa mesma alteridade e desse histórico e forçoso distanciamento. Como o assevera Frank R. Ankersmit,

Apenas porque e na medida em que nos tornamos conscientes de uma diferença e de uma distância entre nós mesmos - ou seja, o sujeito histórico - e o passado é que a escrita da história pode tornar-se um empreendimento cultural significativo. ${ }^{54}$

Aqui, faz-se preciso lançar um alerta. Se nos inserimos em uma tradição crítica, se somos herdeiros de métodos, de um arsenal teórico, de instrumentos de inteligibilidade dos textos, isso não quer dizer que devemos nos contentar com nossa herança, sobretudo quando ela nos obriga a ver sempre os objetos a partir de um mesmo prisma, que, paradoxalmente, refrata às avessas a luz da história impedindo-nos de reconhecê-la em sua diferença. $O$ que se censura à filologia de base neolachmanniana é que, sob sua aparente

${ }^{52}$ CUNHA, Celso. Significância e Movência na Poesia Trovadoresca: Questões de crítica textual. Rio de Janeiro: Tempo Brasileiro, 1985, p. 17.

53 Idem, p. 25.

${ }^{54}$ ANKERSMIT, Frank R. Historicismo, "Pós-modernismo e historiografia”. In: MALERBA, Jurandir (Org.). A História Escrita: Teoria e história da historiografia. São Paulo: Contexto, 2006, pp. $95-114$ [p. 98]. 
neutralidade, em sua ingenuidade real ou fingida, em sua busca pela restituição do texto dito genuíno, ela carreia consigo um sistema de valores que, em nosso país, quiçá por inércia mental, se tem ajuizado como portador de validade trans-histórica. É como se o que concernisse às tradições a serem editadas fosse apenas contingencialmente histórico ${ }^{55} \mathrm{e}$ também como se a interpretação fosse ao mesmo tempo uma projeção idealizada e "crítica" do interpretado. Ainda somos herdeiros de uma prática filológica em que, a par de uma busca por objetividade (que é controlada metodicamente [por mais problemáticos que os métodos sejam], é o que se crê - lembremo-nos da estemática de Paul Maas ${ }^{56}$, por exemplo), há elementos politicamente motivados, sem que tenhamos idéia hoje em dia de sua constante presença. Para a filologia do século XIX, cuja preocupação central era resgatar os monumentos literários da nacionalidade em que esta se tornava manifesta em seu contínuo devir, a idéia de autoria era também ela central, pois representava, sob a rubrica da "genialidade", o ápice da criatividade de uma coletividade que se estruturava na forma do moderno Estado-nação. Capital simbólico, em seu conjunto, de uma coletividade que então se organizava, coube à filologia do século XIX a tarefa de brunir esses monumentos para que se nos mostrassem em seu "prístino esplendor", aquele do que se supunha ser a parole autoral original. Função política de construção de representações coesivas e identitárias, a filologia, por meio do trabalho de restituição que se propôs, "denotou”“o seu lugar e importância na vida cotidiana, seu papel na vida pública e os interesses que determinam seu processo cognitivo como fatores decisivos para sua forma" ${ }^{17}$, historicamente situada no século XIX, mas que perdurou século XX adentro.

A crítica ao neolachmannismo torna-se possível e necessária ao se poder reconhecer no momento em que escrevemos a relação entre o seu discurso, o do lachmannismo, e aquilo que implica sem o dizer, ou seja, a relação entre sua coerência e sua gênese, relação que denota suas possibilidades e limitações. Ao lidar com as tradições que são seu objeto, a filologia do século XIX e aquelas dos séculos XX e XXI, que são suas herdeiras e que Ihe dão continuidade, entenderam "tradição" como o processo histórico de "transmissão e destruição de lembranças, imagens, objetos, textos" ${ }^{\prime \prime 8}$. Como a compreensão dos fins a que almejava a disciplina implicava a restituição do que fora "destruído" ou "derruído" durante o processo transmissional, e como a transmissão por cópia no âmbito da cultura da

55 ZERNER, Henri. Op. cit., p. 145.

${ }^{56}$ MAAS, Paul. Critica del Testo. Traduzione di Nello Martinelli, presentazione di Giorgio Pasquali, con lo "Sguardo retrospettivo 1956" e una nota di Luciano Canfora. Firenze: Felice Le Monier, 1990.

57 BLANKE, Horst Walter. "Para uma nova história da historiografia". In: MALERBA, Jurandir (Org.). A História Escrita: Teoria e história da historiografia. São Paulo: Contexto, 2006, pp. 27-64 [p. 41$].$

58 MASTROGREGORI, Massimo. "Historiografia e tradição das lembranças". In: MALERBA, Jurandir (Org.). A História Escrita: Teoria e história da historiografia. São Paulo: Contexto, 2006, pp. 65-93 [p. 70 ]. 
manuscritura gerava por necessidade "erros"59 - ou seja, destruição -, "erros" e destruição passaram a se equivaler. A filologia do século XIX, em sua busca por tornar-se um conhecimento científico, partiu de um monismo epistemológico, e, como área do saber, tentou preencher requisitos reconhecidos como inerentes à ciência, "notadamente a capacidade para construir procedimentos metodológicos de descrição da 'realidade' observada e nela encontrar regularidades traduzíveis em leis cognitivas". Assim, por uma proposição universalmente válida, que explicitaria o processo de gradual corrupção por que passariam todos os textos em tradições manuscritas, o editor crítico aplicaria o remédio ecdótico que consistiria em reverter pari passu esse mesmo processo - regularidade do fato histórico (corrupção das tradições), procedimentos metodológicos de descrição da "realidade" (por exemplo, a estemática de Paul Maas, e os antídotos editoriais à corrupção por reversão do processo de depauperamento da tradição; a patologia da atenção de Louis Havet ${ }^{60}$ ), estabelecimento de leis cognitivas respeitantes tanto ao processo de depauperamento como às modalidades de restituição do texto ${ }^{61}$.

No que respeita à tradição, a filologia do século XIX e suas herdeiras sempre estiveram mais interessadas nos produtos e em sua "restituição" do que em "processos", de que as tradições são o resultado, sendo que por "processos" passou-se a compreender somente o procedimento de cópia e de conseqüente proliferação de "erros", corolários daquela, como se "processo" pudesse no âmbito filológico ser equalizado ao ato de copiar e de "errar". Mas, mesmo que se compreendesse processo como o conjunto de ações destrutivas e de dispersões - com o que não concordamos -, ainda assim, como o diz Massimo Mastrogregori, não se pode menosprezar as "ações destrutivas e as dispersões (o filólogo pretende constituir o texto, o administrador de bens culturais, restaurar o monumento), que são, mesmo assim, elementos necessários desse processo histórico, o qual não deve ser considerado teleologicamente" ${ }^{\prime \prime 2}$. Mas a tradição, enquanto produto de um processo, sofreu e sofre a ação das mais variadas forças históricas, podendo ser considerada, por

59 SPINA, Segismundo. Op. cit., 1994, p. 104.

${ }^{60}$ HAVET, Louis. Manuel de critique verbale appliquée aux textes latins. Paris: Hachette, 1911.

${ }^{61}$ Arno Wehling, ao discorrer sobre as aporias que viciaram, nos séculos XIX e XX, a operação historiográfica, fala da "naturalização dos conceitos" (uma dessas aporias) nos termos que se seguem: "O uso atemporal dos conceitos - por exemplo, quando o grande helenista Gustave Glotz refere-se à burguesia ateniense do século IV como se tal categoria fosse igualmengte válida para o seu tema e para a época em que vivia, a da III República francesa - remete à mera aplicação de um 'senso comum' de linguagem, ou implica admissão de'realidades' trans-históricas e trans-culturais? Estaríamos diante de um simples empirismo despreocupado de questões teóricas e metodológicas ou de uma metafísica implícita/ inconsciente?" (WEHLING, Arno. "Historiografia e epistemologia histórica”. In: MALERBA, Jurandir (Org.). A História Escrita: Teoria e história da historiografia. São Paulo: Contexto, 2006, pp. 175-189 [p. 185].

${ }^{62}$ MASTROGREGORI, Massimo. Op. cit., p. 70. 
muitos de nós hoje em dia - o que constitui etapa desse mesmo processo - como restos de um circuito comunicacional que a filologia tem sonhado recuperar ao menos no que respeita ao resgate da mensagem em seu estado primeiro; como produto do exercício das formas de domínio e de direito (por exemplo, da propriedade), relativamente a um campo disciplinar ou a campos disciplinares complementares e/ou concorrentes (Filologia e História Literária, por exemplo), que reservam para si o ius de legitimar as tradições na medida em que delas se apoderam por meio de seus métodos críticos.

A ação de apropriação das tradições no âmbito filológico é vista pelos filólogos, no que concerne à recuperação do circuito comunicacional, como restituição da mensagem sem levar em consideração a historicidade do próprio circuito, o que os conduz inevitavelmente a uma má compreensão da natureza da mensagem. No que respeita à apropriação da tradição pelo exercício de um domínio e de um direito, a filologia legitima-se ao se declarar força de conservação da memória e do patrimônio escritos, enquanto, ao mesmo tempo, declara a premente necessidade de intervenção nas tradições com vistas a deter o processo de deterioração que lhes é imanente e a restituir a mensagem, o que só ela tem autoridade para empreender de forma satisfatória. Os textos autorizados são aqueles ditos críticos, modelados a partir de um método e de seus pressupostos, no entanto invariáveis frente a tradições historicamente muito variáveis. Pode-se dizer que a filologia praticada por muitos filólogos tem um meta-estatuto irrefletido e é ela que afiança a modelização e a legitimação das tradições restituídas. A filologia dos neolachmannianos instituiu como comunicação "competente" aquela centrada na figura do autor, circuito comunicacional fechado, em que produção, publicação e apropriação estão pré-determinadas pelo preconceito que têm os filólogos do próprio circuito. Os filólogos deveriam lembrar-se com mais freqüência das palavras de Massimo Mastrogregori:

É-nos proibido, em outros termos, enrolar de acordo com a nossa vontade o fio que nos liga ao passado, como no Thésée de A. Gide, do outro lado do novelo há alguém que desenrola o fio de acordo com a sua vontade, empurrado por razões e segundo condições que nos é preciso reconstruir e explicar. ${ }^{63}$

\section{(II.6)}

A filologia da re-fundação não se detém na análise dos processos mentais, que são sempre eles próprios dotados de uma dada historicidade, "por meio dos quais uma reminiscência interpretativa do passado ganha a qualidade específica daquilo que nós chama-

63 Idem, pp. 72-73. 
mos 'história'"'64 ou filologia e, nesse sentido, não consegue se perceber como aquilo que é, romântica, "by an uncritical absorption in Romanticism's own self-presentation"65. Se a Filologia é uma disciplina histórica, só o pode plenamente ser se "the past and its works" forem estudados "in the full range of their pastness - in their differences and their allienations (both contemporary and historical)" ${ }^{\prime \prime 6}$. A reconstrução filológica, para ser autocrítica, deveria prestar atenção aos "princípios de sentido" que balizam o seu fazer e que determinam a lógica de sua interpretação e a retórica de constituição de suas representações. Para os neolachmannianos, o problema do status ontológico da verdade, que obcecou a reflexão historiográfica durante boa parte do século passado, é abolido por simplificação, já que se deseja estabelecer para a ficcionalidade da poesia, por meio de procedimentos críticos invariáveis, sua facticidade - embora ficta, os verba fixados pelo filólogo foram proferidos ou inscritos por um auctor em um exato tempo-espaço, que a crítica filológica é capaz de fazer soar novamente, e, desse modo, restitui o dictum produzindo por essa operação restituidora o fato histórico, que equivale ao documento editado. É essa certeza positiva o fim a que almeja toda a filologia dos neolachmannianos. Pode-se dizer que para ela, com Vico, é válido o aforismo verum ipsum factum? Mas como pode a busca pelo verum ipsum factum coadunar-se, entre os neolachmannianos, com uma práxis filológica em que, mais do que haver a possibilidade de identidade entre sujeito e objeto, haja a preconização da necessidade dessa mesma identidade? Por paradoxal que isso possa nos parecer hoje em dia, essa preconização de que falamos não implica no âmbito de uma disciplina histórica como o é a filologia a constituição da história (res gestae) pela historiografia (historia rerum gestarum) - o que implica ponto de vista, perspectivação, subjetividade, juízo, precariedade, modalidades de narrativização etc. -, mas antes a possibilidade da identidade entre res gestae e historia rerum gestarum de forma absoluta e não relativa. A proposição da identidade entre sujeito e objeto subjaz à interpretatio, sendo que a interpretação visa a equivaler o texto interpretado e fixado ao texto ideado e inscrito pelo autor, o que parece remeter a uma concepção hermenêutica que se concebe como "arte da compreensão correta do discurso de um outro"67, necessariamente de uma autoria a que o texto precisa ser remetido para ser devidamente interpretado e fixado, concepção essa claramente apresentada por Schleiermacher em seus escritos, mas partilhada, por exemplo,

64 RÜSEN, Jörn. "Historiografia comparativa intercultural”. In: MALERBA, Jurandir (Org.). A História Escrita: Teoria e história da historiografia. São Paulo: Contexto, 2006, pp. 115-137 [p. 119].

${ }^{65}$ McGANN, Jerome J. The Romantic Ideology: A Critical Investigation. Chicago/London: The University of Chicago Press, 1985, p. 1.

66 Idem, p. 2.

67 SCHLEIERMACHER, D. E. Hermenêutica. Arte e técnica da interpretação. 3. a ed., Petrópolis: Vozes, 2001. 
por Luciana Stegagno Picchio, que cita, como auctoritas, não o referido autor alemão, mas Wilamowitz Möllendorf:

meta derradeira que o filólogo se propõe e que continua sendo sempre a mesma: entender, no sentido mais amplo do termo, quanto um outro homem, mesmo distante no tempo e no espaço, confiou aos signos; reproduzir em si o processo histórico e o momento intuitivo que levou àquela expressão lingüística e poética ou, como dizia com uma bela imagem Wilamowitz, "captar uma personalidade alheia. ${ }^{68}$

O entrecruzamento da filologia e da hermenêutica, no século XIX e início do XX - embora, como se disse, haja uma força inercial que as mantém unidas ainda nos dias de hoje -, nada mais faz do que reforçar o princípio da coerência cognitiva, que pode ser assim resumido: "uma teoria que vai obter um lugar permanente no repertório público daquilo que é conhecido precisará entremear-se aos procedimentos que garantem outros tipos de teorias" ${ }^{\prime 69}$.

É a captação de uma personalidade alheia o que propõem Celso Cunha ${ }^{70}$, Antônio Houaiss $^{71}$, Segismundo Spina ${ }^{72}$, Leodegário A. de Azevedo Filho ${ }^{73}$, César Nardelli Cambraia $^{74}$, Barbara Spaggiari e Maurizio Perugi ${ }^{75}$, dentre outros, somente para nos ater àqueles que publicaram manuais introdutórios à crítica textual e à ecdótica entre nós.

A recusa ao método de Lachmann e a seus derivativos é uma recusa ao seu meta-status crítico e à sua metalinguagem enceguecedora. Como já o disse Michel de Certeau: "Recusar a ficção de uma metalinguagem que unifica o todo é deixar transparecer a relação entre os procedimentos críticos limitados e aquilo que lhes falta do 'real' ao qual se referem"76, recusa essa importante, pois, ao evidenciar sua precariedade, impede a afirmação do dogma, como o diz ainda Michel de Certeau, da "adequação" do discurso ao real, dogma esse que institui a relação dos fatos como procedimento doutrinal ${ }^{77}$.

68 PICCHIO, Luciana Stegagno. A Lição do Texto. Filologia e Literatura: I - Idade Média. Lisboa: Edições 70, 1979, pp. 209-235 [p. 214].

69 DOUGLAS, Mary. Op. cit., 1998, p. 82.

70 CUNHA, Celso. Op. cit., 1995.

71 HOUAISS, Antônio. Elementos de Bibliologia. São Paulo: Hucitec/Pró-Memória/Instituto Nacional do Livro, 1983.

72 SPINA, Segismundo. Op. cit., 1994.

73 AZEVEDO FILHO, Leodegário A. de. Op. cit., 1987.

74 CAMBRAIA, César Nardelli. Op. cit., 2005.

75 SPAGGIARI, Barbara \& PERUGI, Maurizio. Fundamentos da Crítica Textual: História, metodologia, exercícios. Rio de Janeiro: Lucerna, 2004.

76 CERTEAU, Michel. Op. cit., 2002, pp. 10-11.

77 Idem, p. 11. 
Cremos ser tempo para que se escreva uma história do processo intelectual do conhecimento filológico que produza, a par da descrição de teorias e métodos utilizados no passado assim como no presente, "teorias e problemas aplicados a uma crítica da razão científica"78.

\section{(II.7)}

Em manuais de crítica textual publicados no Brasil, seja naqueles de autoria de filólogos brasileiros, seja em manuais de filólogos italianos, repetem-se à exaustão modelos de interpretação e métodos editoriais propostos em manuais anteriores ou em edições críticas ajuizadas com base suficiente para a produção de modelizações. Neles, há o acúmulo de um capital ou seguro de explicações paradigmáticas e sistemáticas que mutuamente se apóiam $^{79}$. Esses manuais, contudo, não se propõem ser uma história dos métodos filológicos, ou, quando tangenciam a história da disciplina, só o fazem para tentar demonstrar o telos inescapável de nosso campo disciplinar, atemporal, como se a filologia, desde seus primórdios, houvesse de uma vez por todas determinado sua finalidade e encontrado os meios, crescentemente, para a sua consecução. Talvez a falta de histórias dos métodos filológicos ${ }^{80}$ caminhe pari passu com aquela dos métodos históricos em forma monográfica, já assinalada dentre outros por Horst Walter Blanke ${ }^{81}$, conquanto seja preciso dizer que, contrariamente à profusão de reflexões que problematizaram o campo historiográfico e o fazer história durante o século passado, a renovatio filológica mostrou-se muito mais acanhada e foi, quando houve, criticada muita vez de forma superficial e infundada por aqueles que, frente a quaisquer tradições filológicas, querem-nas autorizadas e definitivas ${ }^{82}$. Em

78 WEHLING, Arno. Op. cit., p. 177.

79 BLANKE, Horst Walter. "Para uma nova história da historiografia". In: MALERBA, Jurandir (Org.). A História Escrita: Teoria e história da historiografia. São Paulo: Contexto, 2006, pp. 27-64 [p. 33].

80 Uma bela exceção ao que acabamos de assertar é o livro seminal de Sebastiano Timpanaro sobre a gênese do método dito lachmanniano. Vide TIMPANARO, Sebastiano. La Genesi del Metodo del Lachamann. Seconda Ristampa, Padova: Liviana Editrice, 1990.

81 BLANKE, Horst Walter. Op. cit., p. 30.

${ }^{82}$ Assim age, por exemplo, Barbara Spaggiari, que supõe desautorizar a New Philology valendo-se de duas auctoritates, a de Philippe Ménard e a de Cesare Segre, cujos textos não são, ao contrário do que seria de esperar, comentados pela filóloga italiana em seu livro. A citação nominal para ela parece ser prova conclusiva do que assevera. Para uma crítica do livro de Spaggiari, de sua asserção descabida de que a New Philology não tem valor científico e para um detido comentário aos textos de Philippe Ménard e de Cesare Segre, vide MOREIRA, Marcello. "O problema da edição de apógrafos de Santa Rita Durão". In: FRANCO, Márcia Arruda, LINDO, Luiz Antônio \& SEABRA, José Rodrigues Seabra (Org.). Atas da IV Semana de Filologia na USP. São Paulo: Faculdade de Filosofia, Letras e Ciências Humanas da Universidade de São Paulo, 2009, no prelo. 
filologia, também não há a escrita de uma história das funções do pensamento filológico ${ }^{83}$, como sói acontecer no âmbito da história, em que há interesse crescente pelas histórias das funções do pensamento histórico ${ }^{84}$.

\section{(III)}

Entende-se edição crítica em nosso país como aquela que visa a restituir ao texto a sua genuinidade ${ }^{85}$, já que, em se lidando com cópias apógrafas, haveria a certeza de estarem eivadas de erros, pois, como preconiza um velho aforismo conhecido de todo filólogo, quem diz cópia diz erro ${ }^{86}$, e caberia ao crítico textual, por conseguinte, subtrair do/s testemunho/s os erros que se imiscuíram paulatinamente nos membros da tradição manuscrita sob estudo ou no único testemunho que a constituiria ${ }^{87}$.

Quando o filólogo se depara com um único testemunho apógrafo, como é o caso de que ora tratamos, Segismundo Spina recomenda que o texto só deva ser corrigido quando o erro é certo, mantendo-se as demais passagens intactas ${ }^{88}$. Leodegário A. de Azevedo Filho preconiza que o tratamento filológico de codex unicus implica a fixação do texto a partir do juízo crítico ${ }^{89}$, iudicium, não declarando, contudo, como o faz Segismundo Spina, que as intervenções do editor devam recair somente sobre as passagens que seriam "erros evidentes". A correção dos "erros evidentes", entretanto, não havendo mais do que um testemunho, só se pode fazer por meio da divinatio, é claro, mas seria preciso discutir previamente a qualquer tentativa de fixação do texto crítico o que se compreende como "erro evidente", categoria ambígua e de difícil definição, como já discutimos em outro trabalho ${ }^{90}$.

${ }^{83}$ Duas belas exceções são os artigos escritos, o primeiro, por Hans Ulrich Gumbrecht - sobre as relações entre filologia e nacionalismo na França do século XIX -, e o segundo, por Joan Ramon Resina - sobre Ramón Menéndez Pidal, Filologia e Nacionalismo na Espanha do Século XX, já citados.

${ }^{84}$ BLANKE, Horst Walter. Op. cit., p. 31.

${ }^{85}$ Ver, por exemplo, SPINA, Segismundo. Op. cit., 1994, p. 27 e seguintes; AZEVEDO FILHO, Leodegário A. de. Iniciação em Crítica Textual. Op. cit., 1987, p. 16 e seguintes; e também CAMBRAIA, César Nardelli. Op. cit., 2005 , p. 1, entre outras. Para uma crítica da equalização entre edição crítica e edição que vise a recuperar a genuinidade dos textos, ver MOREIRA, Marcello. "Notas sobre crítica textual, mouvance, variance." In: FRANCO, Márcia Arruda, LINDO, Luiz Antônio \& SEABRA FILHO, José Rodrigues (Org.). Atas da III Semana de Filologia da USP. São Paulo: FFLCH, 2009, no prelo, e, também, MOREIRA, Marcello. Critica Textualis in Caelum Revocata? Uma Proposta de Edição e Estudo da Tradição de Gregório de Matos e Guerra. São Paulo: Edusp, 2011.

${ }^{86}$ SPINA, Segismundo. Op. cit., 1994, p. 113.

${ }^{87}$ AZEVEDO FILHO, Leodegário A. de. Op. cit., 1987, p. 26.

88 SPINA, Segismundo. Op. cit., 1994, p. 114.

${ }^{89}$ AZEVEDO FILHO, Leodegário A. de. Op. cit., 1987, p. 39.

${ }^{90}$ MOREIRA, Marcello. Critica Textualis in Caelum Revocata? Uma Proposta de Edição e Estudo da Tradição de Gregório de Matos e Guerra. São Paulo: Edusp, 2011;. 
No caso da Écloga Piscatória, dever-se-ia ou não inserir [suplere] vocábulos nos versos ou deles retirar [delere] elementos com vistas a produzir uma absoluta isometria? Para o caso em questão, a resposta não parece difícil, pois o poema se estrutura a partir da adoção de um regular isossilabismo, que não se encontra, por exemplo, em muitos dos poemas atribuídos a Gregório de Matos e Guerra e na poesia dos trovadores, que demandam, por conseguinte, soluções ecdóticas diferentes.

Para Segismundo Spina, recuperar a genuinidade do texto significa:

aproximá-lo o mais possível da última vontade do seu autor; facilitar a sua leitura consiste em torná-lo legível através das normas da restauração, no caso de o texto haver chegado até nós corrompido ou adulterado, por omissões, rasuras, interpolações, correções intencionais, distrações involuntárias, erros tipográficos (se o texto é posterior à invenção da imprensa), enfim - defeitos e deturpações de toda ordem; torná-lo inteligível e interpretá-lo, pontuando-o racionalmente e elucidando as alusões de ordem geográfica, histórica, mitológica, isto é, com o auxílio das disciplinas subsidiárias da Filologia [...]..$^{91}$

Como se entende do fragmento acima excertado, cabe ao filólogo, diante de apógrafo a ser editado, torná-lo inteligível, e, para tanto, dentre outras operações que objetivam sua inteligibilidade pelo público contemporâneo do editor, é necessário pontuá-lo "racionalmente". Entre as etapas da crítica conjectural, Leodegário A. de Azevedo Filho elenca interpungere, mutare, transponere, delere e supplere ${ }^{92}$, significando a primeira delas: "pontuar adequadamente um texto sem pontuação ou com escassa e insuficiente pontuação, tarefa mais complexa do que se pensa à primeira vista"93. Parece-nos, pela leitura conjunta e complementar dos textos dos dois filólogos acima citados, que a pontuação "racional" de que fala Segismundo Spina equivalha à prática do interpungere, na medida em que, não sendo a pontuação autoral, mas "espúria", caberia ao filólogo conjecturalmente "restituí-la" para recuperar a "racionalidade" do texto comprometida pelo processo transmissional. Mas cabe dizer que mesmo sendo autoral, a pontuação não teria o caráter "racional" de que fala Segismundo Spina, pois o pontuar é procedimento de organização do texto que varia historicamente, não havendo uma única "racionalidade" subjacente à prática da pontuação, ou seja, não há uma pontuação racionalmente trans-histórica. Para que a emendatio ope conjecturae restituísse o texto filologicamente no que respeita ao interpungere, seria necessário recuperar os critérios de pontuação coetâneos do texto a ser editado, já

\footnotetext{
91 SPINA, Segismundo. Op. cit., 1994, p. 87.

${ }_{92}$ AZEVEDO FILHO, Leodegário A. de. Op. cit., 1987, p. 57.

${ }^{93}$ Ibidem.
} 
que a crítica textual visa à recuperação do texto dito "genuíno", genuinidade essa que pressupõe, por razões óbvias, que a pontuação seja elemento constituinte do texto dito "genuíno" e que seja, tanto quanto o é a palavração do texto a ser editado, marcada por uma dada historicidade, que caberia ao filólogo preservar e restituir. Mas, embora se fale em Segismundo Spina e Leodegário A. de Azevedo Filho de restitutio textus, o procedimento crítico implicado na expressão não parece dizer respeito à recuperação de uma pontuação "genuína", o que se nos afigura paradoxal. Leodegário A. de Azevedo Filho, por exemplo, em sua edição das cantigas de Pero Meogo, propõe que se pontue os textos do jogral galego-português "conforme a sintaxe do texto"94, o mesmo propondo para sua edição da "lírica" de Luís de Camões ${ }^{95}$, ou seja, conforme padrões de organização sintagmática que lhe parecem, a ele, editor, "racionais", segundo formas de inteligibilidade que lhe são contemporâneas, mas que são obviamente extemporâneas dos poetas e de seu público primeiro. Se se ajuíza o autor núcleo de expressão e de inscrição, que é garantia da "unidade" iniludível das obras, expressão e inscrição a que se subsume, por exemplo, a pontuação, há muito a ecdótica de que Segismundo Spina e Leodegário A. de Azevedo Filho são representantes deveria ter se detido no estabelecimento de procedimentos de seleção e de exclusão que visariam à fixação da pontuação a mais autoral possível por meio dos textos que os testemunhos apógrafos nos fornecessem, ou seja, dever-se-ia procurar meios para excluir as marcas ou sinais que na escritura estão desprovidos de "qualidade", mas que pudessem ao mesmo tempo manter os que portam "autoridade".

É preciso determo-nos aqui por uns instantes na discussão levada a termo por Walter Greg e por Fredson Bowers sobre elementos textuais substantivos e acidentais, pois tal discussão é de capital importância para a resolução do problema da efetuação de uma pontuação "racional" tal como é preconizada por Segismundo Spina e Leodegário A. de Azevedo Filho.

Walter Greg distingue "elementos substantivos" de "elementos acidentais", sendo os primeiros compostos basicamente da palavração dos textos, elementos esses que segundo o filólogo inglês afetariam de forma propriamente dita a expressão do autor, caso fossem alterados, sendo que os acidentais respeitariam à pontuação, à capitalização, à grafia e à divisão de palavras, ou seja, à apresentação visual do texto ${ }^{96}$. A prática editorial da escola filológica anglo-saxã, fortemente documental e pouco afeita, por conseguinte, à moder-

${ }^{94}$ AZEVEDO FILHO, Leodegário A. de. As Cantigas de Pero Meogo. Rio de Janeiro: Gernasa, 1974, p. 32.

${ }^{95}$ AZEVEDO FILHO, Leodegário A. de. Op. cit., 1987, pp. 59-60

96 GREG, Walter."The Rationale of Copy-Text". In: BRACK JR. O. M. \& BARNES, Warner. Bibliography and Textual Criticism. English and American Authors: 1700 to the Present. Chicago and London: The University of Chicago Press, 1969, pp. 41-58 [p. 43]. 
nização, fundamenta-se na manutenção dos elementos substantivos no que respeita ao seu aspecto, por exemplo, grafemático, "since spelling is now recognized as an essential characteristic of an author, or at least of his time and locality" ${ }^{\prime \prime 97}$. Compreende-se facilmente a partir do excerto que, se o intento é recuperar a genuinidade do texto, essa restitutio implica por razões óbvias a manutenção da grafia desejada pelo autor, pois, para além de ser um documento que atesta a prática escritural de um auctor, é, ao mesmo tempo, um documento que evidencia uma etapa da história da língua e de seus usos poéticos e letrados. Como é a historicidade do testemunho que se objetiva preservar com a prática da manutenção da grafia de documentos pretéritos, mesmo que o testemunho não seja autoral, se a mantém, ainda assim, pois, com certeza, como o diz Walter Greg, quanto mais próximo for do autor o testemunho, mais será representativo de sua prática de escrita, porque representativo da prática de escrita de sua época. Por isso, ele afirma uma vez mais: "It is therefore the modern editorial practice to choose whatever existant text may be supposed to represent most nearly what the author wrote and to follow it with the least possible alteration." ${ }^{18}$ Os elementos substantivos teriam de ser restituídos pela crítica textual, enquanto a grafia do apógrafo, se contemporâneo do autor, poderia ao menos representar parte da grafia autoral e, por essa razão, deveria ser mantida pelo editor. Walter Greg sabe, entretanto, que quanto mais tardia for a cópia relativamente ao original, maiores são as chances de que as discrepâncias entre eles aumentem, sobretudo no que concerne aos acidentais, pois uma forma histórica de notação passa a ser sistematicamente substituída por outra. Quando do tratamento de tradições constituídas de impressos, é preciso, segundo Walter Greg, adotar como copy-text ou exemplar de base a edição mais antiga, sobretudo no que concerne aos acidentais, pois, embora possa haver erros no impresso que talvez possam ser corrigidos por uma outra impressão realizada independentemente a partir do manuscrito, é de supor que os membros de uma oficina tipográfica, contemporâneos do autor, mantenham parte significativa dos acidentais autorais, incluindo-se entre esses a grafia e a pontuação, já que estariam afeitos à prática notacional autoral ${ }^{99}$. O mesmo diz Fredson Bowers, ao afirmar que, em uma tradição impressa, em que apenas a primeira edição derivou com certeza do manuscrito autoral, é preciso adotar como copy-text a editio princeps, já que nela haveria ao menos preservação de parte dos acidentais autorais ${ }^{100}$ :

\footnotetext{
97 Idem, ibidem.

98 Idem, ibidem.

99 Idem, pp. 44-45.

${ }^{100}$ BOWERS, Fredson. "Current Theories of Copy-Text, with an Illustration from Dryden". In BRACK JR. O. M. \& BARNES, Warner. Bibliography and Textual Criticism. English and American Authors: 1700 to the Present. Chicago and London: The University of Chicago Press, 1969, pp. 59-72 [p. 59].
} 
There is no space here to discuss with proper thoroughness the real interest residing in the accidentals of a critical old-spelling edition. All bibliographical experience indicates that, in general, a compositor imposes a great deal of his own system on a manuscript text but is, to some extent, influenced by his copy. Thus, although no printed early text can be taken as an over-all faithful representation, it is at best of some authority and at worst it is one which is characteristic of the time in which the work is written and therefore usually consonant with the author's style. ${ }^{101}$

No entanto, em uma outra seção de seu artigo, Walter Greg, ao discorrer sobre a necessidade de se corrigirem erros presentes no/s testemunho/s, afirma que sem essa correção não pode haver edição crítica e, ao mesmo tempo, defende que essa correção se estenda até mesmo aos acidentais, como a grafia, sem, no entanto, estabelecer bases e procedimentos objetivos para que se efetue essa intervenção: "I see no reason why he [o editor] should not alter misleading or eccentric spellings which he is satisfied emanate from the scribe or compositor and not from the author."102 Contudo, em passagem anterior, ao alegar suas razões para que o editor aderisse a um copy-text no que concerne aos acidentais, afirmou: "I suggest that it is only in the matter of accidentals that we are bound (within reason) to follow it [ copy-text]"103, porque, como o próprio Walter Greg disse, linhas acima das antes excertadas, "it is only on grounds of expediency, and in consequence either of philological ignorance or of linguistic circumstances, that we select a particular original as our copy-text" ${ }^{\prime 104}$. Se temos de aderir a um copy-text no que respeita aos acidentais, pois por ignorância filológica e pela falta de um testemunho autógrafo não sabemos como o autor teria de fato notado seu texto e que grafia ele teria produzido, tendo de contentar-nos com grafia e sistema notacional os mais próximos possíveis daqueles autorais, como se diz que o editor pode intervir por exemplo na grafia e alterar a soletração ao ajuizá-la representativa do escriba ou do compositor, mas não do autor? Parece-nos que Walter Greg não tem razão alguma ao propor a possibilidade de se intervir nos acidentais do texto de base com vistas a recuperar a pontuação ou a grafia que supostamente o autor teria visado, mas que o escriba teria deturpado consciente ou inconscientemente, pois é simplesmente impossível destrinçar no testemunho o que seria ainda do autor e o que seria devido a agentes da cultura escribal ou a membros de uma casa impressora.

\footnotetext{
${ }^{101}$ Idem, p. 65.

${ }^{102}$ GREG, Walter. Op. cit., 1969, p. 52.

${ }^{103}$ Idem, p. 44.

${ }^{104}$ Idem, ibidem.
} 
Fredson Bowers, ao tratar de tradições impressas de textos do século XVI a XVIII - nas quais há, por exemplo, uma ou mais edições posteriores à princeps, produzidas a partir de edição prévia revisada, no entanto, pelo autor -, assevera que as lições autorais da edição (ou das edições) mais tardia atinentes aos elementos substantivos devem ser integradas ao copy-text, mas que este último deve ser a edição mais antiga baseada no manuscrito autoral, a princeps, portanto, pois era prática dos autores quinhentistas e seiscentistas revisar os substantivos, mas não os acidentais: "Moreover, at least in the sixteenth and seventeenth centuries, it is unrealistic to believe that a proofreading author ever set himself to restore the texture of the original by altering the usual accidentals of the second compositor [...]"105. Se não é plausível pensar que um autor quinhentista ou seiscentista se deu ao trabalho de verificar em que medida os acidentais de uma segunda edição, baseada em edição anterior por ele anotada, foram modificados pelo segundo compositor, como é possível determinar, somente a partir da colação entre um exemplar da editio princeps e um outro da segunda edição revista - mas não com o exemplar anotado de própria mão pelo autor -, quais alterações nos acidentais existentes nos exemplares da segunda edição revista são devidos de fato ao autor? Não poderiam as alterações nos acidentais ser devidas ao compositor, mas não ao autor ${ }^{106}$ ? É por essa razão que Fredson Bowers critica aqueles que afirmam ser legítimo adotar, juntamente com as alterações autorais substantivas de uma segunda edição revisada, também os acidentais desta mesma segunda edição, pois, como o pensa Fredson Bowers, ao não adotarem os acidentais da segunda edição revisada, não estariam eles, os editores, descartando de forma inconsiderada as possíveis mudanças nos acidentais que o autor poderia ter levado a termo quando da revisão, pois as práticas editoriais no início da imprensa moderna não nos permitem supor a que elementos substantivos e elementos acidentais fosse dispensado pelos autores um mesmo tratamento, e aqueles que não discernem essa diferença de tratamento demonstram ignorância das práticas de revisão de impressos por autores, nos séculos XVI e XVII. Por isso, desautoriza o argumento daqueles que defendem a incorporação ao texto crítico dos acidentais de uma segunda edição revisada e que empreendem essa defesa com a seguinte proposição:

\footnotetext{
${ }^{105}$ BOWERS, Fredson. Op. cit., 1969, p. 61.

${ }^{106}$ Como uma declaração de princípios gerais respeitantes ao grau de intervenção dos compositores em manuscritos autorais, que serviriam de base para a produção de impressos, Fredson Bowers assevera: "general bibliographical experience founded on a close comparison of texts seems to foster the belief that usually, so long as accidentals were not positively wrong or misleading, the author concentrated on substantive revision and was content, as a general rule, to accept the accidentals which normal printing practice had imposed on his work" (Idem, p. 66).
} 
He [o editor] may then be strongly inclined to argue that, although admittedly the general texture of a revised derived edition is one step further removed from that of the author's manuscript, yet in accepting the later texture he is at least not discarding whatever alterations in spelling, punctuation, and capitalization the author may have made. ${ }^{107}$

Vinton Dearing, ao discorrer sobre critérios para a escolha do copy-text, afirma que se uma edição, a quarta, por exemplo, foi declarada pelo próprio autor como tendo sido por ele aprovada em todos os seus elementos constituintes, tanto substantivos quanto acidentais, deve servir, por essa razão, como copy-text ${ }^{108}$. No entanto, caso não haja declaração do autor de que em uma edição posterior à primeira se substancie o texto por ele ajuizado definitivo e a que ele daria seu pleno aval, a prática a ser seguida pelo editor é aquela preconizada por Walter Greg e por Fredson Bowers, ou seja, adotar a editio princeps como copy-text, já que seria baseada no manuscrito do autor e representaria, por mais intervenções que nela houvesse, oriundas de agentes que então laboravam em casas impressoras, o que de mais próximo se pode conceber àquilo que o autor inscreveu em seu manuscrito:

If he [o autor] does not express such approval, however, one reasons that the earliest compositor is at least following copy supplied by the author or descended from the author's manuscript and so represents the author's practice better than any reprint into which further changes have crept. ${ }^{109}$

O que aqui propomos, depois do exposto, é a manutenção dos acidentais do manuscrito apógrafo, não porque seriam mais próximos dos que o autor teria ele próprio produzido em sua escritura - o que, no entanto, é verdade, já que o apógrafo data com certeza da segunda metade do século XVIII e pode inclusive ser coetâneo do autor -, mas porque se caracterizam por um regime de notação marcado por uma dada historicidade que se deve preservar e que ajuizamos constitutivo da "obra" enquanto objeto de circulação, recepção e atualização por e na história. Por que deveríamos manter os acidentais, como a pontuação, caso tivéssemos em mãos os manuscritos autógrafos ${ }^{110}$ ? Só porque saberíamos

\footnotetext{
${ }^{107}$ Idem, p. 63.

${ }^{108}$ DEARING, Vinton A. "Methods of Textual Editing". In: BRACK JR. O. M. \& BARNES, Warner. Bibliography and Textual Criticism. English and American Authors: 1700 to the Present. Chicago and London: The University of Chicago Press, 1969, pp. 73-101 [p. 92].

${ }^{109}$ Idem, ibidem.

${ }^{110} \mathrm{~A}$ adoção da pontuação autoral presente nos mss. é praticada por Vanda Anastácio em sua excelente edição de poemas da Marquesa de Alorna (ANASTÁCIO, Vanda. Sonetos: Marquesa de Alorna. Rio de Janeiro: 7 Letras, 2007).
} 
que são autorais? Isso quer dizer que os copistas não sabiam pontuar, sobretudo aqueles que são contemporâneos do poeta? Os acidentais autorais seriam "racionais", mas os dos apógrafos não? Ao mesmo tempo, não vemos por que não se pode produzir no Brasil uma edição crítica em que se mantenha a grafia do apógrafo, como sói ocorrer em old-spelling editions. No caso de edição crítica baseada em apógrafo único, a edição crítica, fortemente documentária, do tipo old-spelling, aproximar-se-ia de edições que os neolachmannianos não julgam críticas, como, por exemplo, uma edição paleográfica ou uma edição interpretativa, sem, no entanto, identificar-se com qualquer uma delas.

Edições modernizadas podem dar conta perfeitamente de atender às demandas de um público mais lato e, no caso de edição crítica de textos curtos, pode-se perfeitamente apresentar, a par do texto crítico, um texto modernizado, como aqui se propõe.

Cremos ser necessário iniciar uma pesquisa sistemática sobre os sistemas notacionais dos séculos XVI, XVII e XVIII para não descartarmos mais, como sói acontecer no Brasil, os acidentais presentes nos testemunhos sem nos questionar previamente sobre sua significação para o público de então.

Quanto à edição modernizada aqui proposta, terá de ser refeita de acordo com novas apropriações do texto atribuído a Santa Rita Durão em tempo por vir, em que os critérios de normatização/modernização por nós adotados não terão necessariamente mais validade, já que a língua se transforma no tempo e no espaço.

Como já se disse, o trabalho aqui ensaiado é precário e vale como estímulo à reflexão. Como fruto da reflexão e do pontuar problemas, que se pode às vezes resolver e às vezes não, cremos poder dizer que a edição que aqui se propõe é crítica, porque fruto do pensamento crítico diante do fazer histórico de nossa disciplina.

\section{(IV) Critérios adotados para a edição crítica}

Mantivemos a grafia do apógrafo, com exceção do "esse" caudado, que foi substituído pelo grafema hoje em vigor e que já era empregado também majoritariamente no século XVIII;

Mantivemos os sinais de pontuação do ms.;

Antes das estrofes, tornamos íntegros os nomes dos pastores que dialogam, nomes esses que, às vezes, no ms., se nos apresentam de forma abreviada - os acréscimos comparecem entre colchetes [];

Separamos os vocábulos conglomerados;

Reunimos os elementos de um só vocábulo quando separado;

Desenvolvemos as abreviaturas entre colchetes []; 
Usamos chaves simples \{\} para indicar supressão;

Usamos parênteses () para indicar calafetação;

Usamos hífen na ligação de pronomes átonos a formas verbais;

Manteve-se o lineamento do ms.

\title{
(IV.1) Texto crítico
}

\author{
Ecloga Piscatoria \\ de \\ Forgino, e Duriano
}

Ao Nascimento do Principe da Beira por Fr[ei] Jozè

de S[an]ta Rita Durão, Religiozo da Graça.

Forgin[o]

Como vai Duriano o rio ameno

Correndo manço para o mar sereno!

Ali surcando estão com alegre bico

Dous Lavancos, não vês? E hum Massarico,

(5) Toda a praia me infunde huma esperança,

De que ha de ser constante esta bonança.

\section{Durian[o]}

O brando vento assopra, e na agoa pura,

Variando mil vezes a figura,

Faz que duvide ainda, estando vendo,

(10) Se he a vista, ou licor que está tremendo.

\section{Forgino}

As mesmas avezinhas dos Salgueiros,

Entoão os seus cantos lizongeiros

Com mais doce armonia; nem do Prado

O mar se destinguira socegado,

(15) Se quando a diferença no mais perde,

Não fora o mar azul, e o Prado verde.

Não julgas Duriano, que isto seja 
Signal de hum grande bem, que o Ceo dezeja

Conceder aos mortaes? Talves he indicio

(20) De algum innopinado beneficio,

Ver como a terra, o Ceo, o mar, e os ventos

$\mathrm{Na}$ concordia feliz dos elementos,

Gozão de tanta paz, tanto socego,

Como hoje ve nas praias do Mondego.

\section{Duriano}

(25) Não he Furgino vão teo vatecinio,

Pois he certo, que os Astros tem dominio

Para dar-nos talves como pressagos

Indicios de ventura, ou dos estragos.

Parece em dia tal, como o prezente,

(30) Que \{a\}inda o mesmo insencivel gosto sente,

O ar, o Ceo, o clima, o feliz anno

Tudo infunde hũ prazer tão soberano,

Que quando a nossa dita \{a\}ind\{i\}a ignorára

No aprazivel da vista suspeitara

(35) O beneficio immenso do Ceo Santo.

\section{Forgen[o]}

Dize tudo, se podes dizer tanto.

\section{Duriano}

Era o tempo, em que o Sol queimando tudo

Abraza dentro da agoa o peixe mudo,

Quando o ameno Mondego de agoas pobre

(40) Todo o leito de areas nos descobre.

Erão vinte e hum de Agosto, a noite escura,

Quando vimos nascer huma creatura,

Com que o amor, o respeito, e a Magestade

Suprirão nessa noite a claridade.

(45) Naquella noite as Tagides formozas

Virão as mesmas trevas luminozas

Com tanto resplandor, que já vi dia 
Que menos, que essa noite luziria.

Aquelle grande Povo sem segundo

(50) Aonde quazi inteiro habita hum mundo;

Com a luz que reflete, em forma brilha,

Que fes por nunca vista maravilha,

Ver alem da Cidade em tanta fragoa

Outra Cidade mais debaixo da agoa.

(55) O grande pescador, de cuja linha

Meio mundo pendente se sostinha,

Xega ao berço suave onde adormece

Aquelle novo herdeiro que aparece,

Porque no tempo que recea a Parca

(60) Da Luzitania reja a immensa Barca,

Mudo, e immovel ficou no feliz peito:

Extaze paresseo, mas era gosto.

\section{Forgen[o]}

Gosto infalivel he, gloria tão alta,

Que a tanto gosto o sentimento falta.

\section{Durian[o]}

(65) Se viste o Pescador, que já cansado,

Tantas vezes as redes tem lansado;

Quando o peixe se amua, e de repente

Ouve hum suçurro de agoa vehemente,

Levanta, e vendo area em hum so ponto,

(70) Pasma de assombro, e fica meio tonto:

Desta sorte pasmado, alegre, e mudo,

Fica o Rey, fica o Reino, e ficou tudo.

Não ves esses Bateis, e os Barcos todos

Ornados de bandeiras por mil modos?

(75) Huns enxendo todo o ar de alegres gritos,

Outros rompendo em vivas infinitos?

Quaes das Lanxas, lates, e Navetas

Ao Clamor belico(so) das trombetas,

Correspondem soando entre essas minas 
(80) Com o tom nautico, e roubo das buzinas?

Olha... escuta no som que reverbera

Aquelle grande nome, que enxe a esfera:

O gosto /diz/ Joze, Joze, motiva;

Ouve o que diz o Céo... /Forg[ino]/ Diz que viva.

\section{Durian[o]}

(85) Viva o grande Joze Principe Augusto,

Retrato bello de hum Monarca justo,

Fidelissimo Heroe da Santa Igreja,

Viva o Rey, e no Neto immortal seja.

\section{Forgen[o]}

Viva, responde o mar da terra ao canto,

(90) Voe no vento a vos de aplauzo tanto;

Enxa o mundo de assombro, e por segui-la

Que para immortal gloria da Figueira,

Seja eterno o Grão Principe da Beira.

\section{(V) Crítica geral do texto impresso}

Nos versos 30 (Que ainda o mesmo insencivel gosto sente,) e 33 (Que quando a nossa dita aind\{i\}a ignorára,), Francisco Topa subtrai a vogal inicial do vocábulo (\{a\}inda), já que, por meio dessa subtração, pode dar-se a elisão da vogal do pronome (Que), no primeiro dos versos acima transcritos, e também aquela final do vocábulo (dita), com a conseqüente restauração do isossilabismo do poema. Mantém-se ao mesmo tempo o esquema rítmico e acentual. Aqui, concordamos com a solução proposta por Francisco Topa. Há, no verso 33, um erro de cópia (aindia), que deve ser corrigido, já que a única solução por nós conjecturada, a separação de dois vocábulos conglomerados (a india), não atende às demandas do contexto - Francisco Topa não nota o erro de inscrição em seu texto.

No verso 44 (Suprirão nessa noite a claridade.), Francisco Topa lê, em lugar do verbo (suprir) com que se inicia o verso, (Suspiraram), tratando-se de evidente erro de interpretação paleográfica. Os versos imediatamente anteriores falam do nascimento do Príncipe da Beira, aos vinte e um dias de agosto, em uma (noite escura), e não há dúvida de que (amor), (respeito) e (Majestade), sujeitos de (Suprirão), suprem, por meio do nascimento - como se esse fosse um evento cósmico, e é assim que está metaforizado no poema - a (claridade), ou sejam, inteiram-na, completam-na. 
O verso 78 (Ao Clamor belico das trombetas,) é hipométrico. Francisco Topa, em sua edição, permutou o vocábulo (belico), presente no ms., pelo sinônimo (belicoso), que supriria o verso da sílaba que lhe "falta", sem alterar, ao mesmo tempo, o seu sentido. A solução é econômica e a julgamos inteligente, pois mantém ao mesmo tempo o esquema acentual e rítmico. Pode-se aventar que o copista por distração deixou de inscrever a sílaba final do vocábulo, o que é provável, pois a forma (belico), presente no ms., é sinônima de belicoso. Como a Ode apresenta evidente isometria, com manutenção acentual e rítmica em todos os versos, aquele hipométrico demanda normalização. Aqui, adotamos a solução proposta por Francisco Topa.

No verso 80 (Com o tom nautico, e roubo das buzinas?), Francisco Topa em sua edição preferiu enfatizar, por subtração da marca de ressonância nasal (-m) em final de proposição ( $\operatorname{Co}\{m\})$, a elisão, já que se lê, sem sombra de dúvida (Co'o), contando-se para os dois vocábulos uma única sílaba métrica. No entanto, não cremos ser necessária a subtração do grafema (-m), já que há largo uso, na versificação em língua portuguesa, da preposição (com), escrita na íntegra, seguida de vocal, cujo encontro é marcado na leitura por elisão de ressonância nasal. Para larga exposição da matéria, ver CHOCIAY, Rogério. Teoria do Verso. São Paulo: McGraw-Hill, 1979, pp. 18 e seguintes. O manuscrito apresenta o vocábulo (roubo), mas não (rouco), leitura esta presente no texto de Francisco Topa. Não há no texto de Francisco Topa indicação de que se tenha corrigido a lição do ms., e, por essa razão, pensamos que (rouco) tenha sido de fato a interpretação do filólogo português. Não cremos que se deva corrigir o apógrafo, pois se fala do (tom nautico) e, também, do (roubo das buzinas). Parece-nos que se faz menção ao tom náutico das buzinas, e, também, ao seu "roubo" - como que um efeito do tom náutico -, no sentido de "arrebatar" e "enlevar". Pode-se dizer que (roubo) esteja a significar "arroubo", "êxtase", sentido esse que condiz perfeitamente com o contexto. O uso é incomum, é verdade, mas se coadunaria perfeitamente com o conceito de lectio difficilior potior, caso o adotássemos aqui.

\section{(VI) Critérios adotados para a edição modernizada}

1. Eliminamos de forma sistemática as particularidades gráficas sem valor fonológico;

2. Foram modernizadas as grafias dos ditongos orais -ae (-ai), -eo (-eu), -oa (-uá), e, quanto a -ea, normalizou-se seu emprego segundo o uso contemporâneo (-eia), quando representa hodiernamente um tritongo, e, no caso do vocábulo "creatura", alterou-se sua forma para a que hoje em dia vige (criatura);

3. Fixamos os ditongos nasais, normalizando a 3. a pessoa do plural do pretérito perfeito e do presente do indicativo segundo o uso contemporâneo (-am); 
4. Fixamos o emprego da fricativa palatal surda segundo o uso contemporâneo (-ch) e (-x);

5. 12. Atualizamos o emprego dos sinais que representam as sibilantes surdas $(-s),(-c),(-c ̧)$, (-ss), e, também, as sibilantes sonoras (-s), (-z).

6. Atualizamos o emprego das fricativas palatais sonoras segundo o uso contemporâneo (-j) e $(-g)$;

7. Eliminamos as consoantes duplas hoje em dia não mais empregadas;

8. Quanto ao emprego do $h$, seguimos o uso contemporâneo. Assim, eliminamo-lo em palavras, por exemplo, como he;

9. Fixamos o índice de nasalização incidente sobre a vogal -u, (-ũ), segundo o uso contemporâneo (-um);

10. Substituímos o -y pelo (-i) segundo o uso contemporâneo;

11. Empregamos o hífen para ligar os pronomes átonos às formas verbais de que dependem;

12. Empregamos o apóstrofo para indicar a elisão vocálica;

13. Empregamos letras maiúsculas no início de cada verso e nos casos exigidos pelo uso contemporâneo, conquanto tenhamos decidido manter as ocorrências de capitais no início de vocábulos, assim grafados no ms., para produzir ênfase;

14. Desenvolvemos as abreviaturas entre colchetes [];

15. Usamos chaves simples \{\} para indicar supressão;

16. Usamos parênteses () para indicar calafetação;

17. Pontuamos o texto conforme a prática contemporânea.

\section{(VI.1) Texto modernizado}

\section{Écloga Piscatória de Forgino e Duriano}

Ao Nascimento do Príncipe da Beira, por Frei José de Santa Rita Durão, Religioso da Graça.

\section{Forgin[o]}

Como vai, Duriano, o rio ameno

Correndo manso para o mar sereno!

Ali, surcando estão, com alegre bico,

Dous Lavancos, não vês?, e um Maçarico.

(5) Toda a praia me infunde uma esperança

De que há de ser constante esta bonança. 


\section{Durian[o]}

O brando vento assopra e, na água pura,

Variando mil vezes a figura,

Faz que duvide, ainda estando vendo,

(10) Se é a vista ou licor que está tremendo.

\section{Forgino}

As mesmas avezinhas dos Salgueiros

Entoam os seus cantos lisonjeiros

Com mais doce harmonia; nem do Prado

O mar se distinguira sossegado,

(15) Se quando a diferença no mais perde,

Não fora o mar azul, e o Prado verde.

Não julgas, Duriano, que isto seja

Sinal de um grande bem, que o Céu deseja

Conceder aos mortais? Talvez é indício

(20) De algum inopinado benefício

Ver como a terra, o Céu, o mar e os ventos,

$\mathrm{Na}$ concórdia feliz dos elementos,

Gozam de tanta paz, tanto sossego,

Como hoje vê nas praias do Mondego.

\section{Duriano}

(25) Não é, Forgino, vão teu vaticínio,

Pois é certo que os Astros têm domínio

Para dar-nos talvez como pressagos

Indícios da ventura ou dos estragos.

Parece em dia tal, como o presente,

(30) Que \{a\}inda o mesmo insensível gosto sente

O ar, o céu, o clima, o feliz ano;

Tudo infunde um prazer tão soberano,

Que quando a nossa dita $\{a\}$ ind $\{i\} a$ ignorara,

No aprazível da vista suspeitara

(35) O benefício imenso do Céu Santo. 


\section{Forgin[o]}

Dize tudo, se podes dizer tanto.

\section{Duriano}

Era o tempo em que o Sol queimando tudo

Abrasa dentro da água o peixe mudo;

Quando o ameno Mondego de águas pobre

(40) Todo o leito de areias nos descobre.

Eram vinte e um de Agosto, a noite escura,

Quando vimos nascer uma criatura,

Com que o amor, o respeito e a Majestade

Supriram nessa noite a claridade.

(45) Naquela noite, as Tágides formosas

Viram as mesmas trevas luminosas

Com tanto resplandor, que já vi dia

Que menos que essa noite luziria.

Aquele grande Povo sem segundo

(50) Aonde quase inteiro habita um mundo,

Com a luz que reflete, em forma brilha,

Que fez por nunca vista maravilha

Ver além da cidade, em tanta frágua,

Outra cidade mais debaixo da água.

(55) O grande pescador, de cuja linha

Meio mundo pendente se sustinha,

Chega ao berço suave onde adormece

Aquele novo herdeiro que aparece,

Porque no tempo que receia a Parca

(60) Da Lusitânia reja a imensa Barca.

Mudo e imóvel ficou no feliz peito:

Êxtase pareceu, mas era gosto.

\section{Forgin[o]}

Gosto infalível é, glória tão alta, Que a tanto gosto o sentimento falta. 


\section{Durian[o]}

(65) Se viste o Pescador que, já cansado,

Tantas vezes as redes tem lançado,

Quando o peixe se amua, e, de repente,

Ouve um sussurro de água veemente,

Levanta e vendo areia em um só ponto,

(70) Pasma de assombro e fica meio tonto;

Desta sorte pasmado, alegre e mudo

Fica o Rei, fica o Reino e ficou tudo.

Não vês esses Batéis e os Barcos todos

Ornados de bandeiras por mil modos?

(75) Uns enchendo todo o ar de alegres gritos,

Outros rompendo em vivas infinitos?

Quais das Lanchas, lates e Navetas,

Ao clamor belico(so) das trombetas,

Correspondem soando entre essas minas

(80) Com o tom náutico e roubo das buzinas?

Olha... escuta no som que reverbera

Aquele grande nome que enche a esfera:

O gosto (diz) José, José, motiva;

Ouve o que diz o Céu... /Forg[ino]/ Diz que viva.

\section{Durian[o]}

(85) Viva o grande José, Príncipe Augusto,

Retrato belo de um Monarca justo,

Fidelíssimo Herói da Santa Igreja.

Viva o Rei e no Neto imortal seja!

\section{Forgin[o]}

Viva, responde o mar da terra ao canto,

(90) Voe no vento a voz de aplauso tanto;

Encha o mundo de assombro e, por segui-la,

Que para imortal glória da Figueira,

Seja eterno o Grão Príncipe da Beira! 


\section{Bibliografia}

ANASTÁCIO, Vanda. Sonetos: Marquesa de Alorna. Rio de Janeiro: 7 Letras, 2007.

ANKERSMIT, Frank R. "Historicismo, Pós-Modernismo e historiografia". In: MALERBA, Jurandir

(Org.). A História Escrita: Teoria e história da historiografia. São Paulo: Contexto, 2006, pp. 95-114.

ARENDT, Hannah. “O conceito de história - Antigo e moderno”. In: Entre o Passado e o Futuro. São Paulo: Perspectiva, 2009, pp. 69-126.

AZEVEDO FILHO, Leodegário A. de. As Cantigas de Pero Meogo. Rio de Janeiro: Gernasa, 1974.

AZEVEDO FILHO, Leodegário A. de. Iniciação em Crítica Textual. Rio de Janeiro/São Paulo: Presença/Edusp, 1987.

BLANKE, Horst Walter. "Para uma nova história da historiografia”. In: MALERBA, Jurandir (Org.). A História Escrita: Teoria e história da historiografia. São Paulo: Contexto, 2006, pp. 27-64.

BLOCH, Marc. Apologia da História ou o Ofício do Historiador. Rio de Janeiro: Jorge Zahar, 2001. BODEl, Remo. A História Tem um Sentido? Bauru: Edusc, 2001.

BOWERS, Fredson. "Current Theories of Copy-Text, with an Illustration from Dryden”. In BRACK JR. O. M. \& BARNES, Warner. Bibliography and Textual Criticism. English and American Authors: 1700 to the Present. Chicago and London: The University of Chicago Press, 1969, pp. 59-72.

CAMBRAIA, César Nardelli. Introdução à Crítica Textual. São Paulo: Martins Fontes, 2005.

CERTEAU, Michel. A Escrita da História. São Paulo: Forense Universitária, 2002.

CHARTIER, Roger. À Beira da Falésia. A história entre certezas e inquietude. Porto Alegre: Editora da UFRGS, 2002.

CHOCIAY, Rogério. Teoria do Verso. São Paulo: McGraw-Hill, 1979.

CUNHA, Celso. Significância e Movência na Poesia Trovadoresca: Questões de crítica textual. Rio de Janeiro: Tempo Brasileiro, 1985.

DEARING, Vinton A. "Methods of Textual Editing". In: BRACK JR. O. M. \& BARNES, Warner. Bibliography and Textual Criticism. English and American Authors: 1700 to the Present. Chicago and London: The University of Chicago Press, 1969, pp. 73-101.

DOUGLAS, Mary. Como as Instituições Pensam. São Paulo: Edusp, 1998.

GINZBURG, Carlo. "Sinais: Raízes de um paradigma indiciário". In: Mitos, Emblemas e Sinais: Morfologia e história. São Paulo: Companhia das Letras, 1989, pp. 143-179.

GREG, Walter. "The Rationale of Copy-Text". In: BRACK JR. O. M. \& BARNES, Warner. Bibliography and Textual Criticism. English and American Authors: 1700 to the Present. Chicago and London: The University of Chicago Press, 1969, pp. 41-58.

GUMBRECHT, Hans Ulrich. “Un souffle d'Allemagne ayant passé: Friedrich Diez, Gaston Paris, and the Genesis of National Philologies". Romance Philology, Berkeley, 40, 1986, pp. 1-37. 
HANSEN, João Adolfo. "Barroco, neobarroco e outras ruínas". In: Floema: Caderno de Teoria e História Literária, Vitória da Conquista, 2 A, 2006, pp. 15-84.

HAVET, Louis. Manuel de critique verbale appliquée aux textes latins. Paris: Hachette, 1911.

HOUAISS, Antônio. Elementos de Bibliologia. São Paulo: Hucitec/Pró-Memória/Instituto Nacional do Livro, 1983.

MAAS, Paul. Critica del Testo. Traduzione di Nello Martinelli, presentazione di Giorgio Pasquali, con lo "Sguardo retrospettivo 1956" e una nota di Luciano Canfora. Firenze: Felice Le Monier, 1990.

MASTROGREGORI, Massimo. "Historiografia e tradição das lembranças". In: MALERBA, Jurandir (Org.). A História Escrita: Teoria e história da historiografia. São Paulo: Contexto, 2006, pp. 65-93. McGANN, Jerome J. The Romantic Ideology: A Critical Investigation. Chicago/London: The University of Chicago Press, 1985.

MORAES, Rubem Borba. Bibliografia Brasileira do Período Colonial. São Paulo: Instituto de Estudos Brasileiros da Universidade de São Paulo, 1969.

MOREIRA, Marcello. "O problema da edição de apógrafos de Santa Rita Durão". In: FRANCO, Márcia Arruda; LINDO, Luiz Antônio \& SEABRA, José Rodrigues Seabra (Org.). Atas da IV Semana de Filologia na USP. São Paulo: Faculdade de Filosofia, Letras e Ciências Humanas da Universidade de São Paulo, 2010.

MOREIRA, Marcello. "Notas sobre crítica textual, mouvance, variance."In: FRANCO, Márcia Arruda; LINDO, Luiz Antônio \& SEABRA FILHO, José Rodrigues (Org.). Atas da III Semana de Filologia da USP. São Paulo: FFLCH, 2009, no prelo.

MOREIRA, Marcello. Critica Textualis in Caelum Revocata? Uma proposta de edição e estudo da tradição de Gregório de Matos e Guerra. São Paulo: Edusp, 2011.

NAGY, Gregory. Poetry as Performance: Homer and Beyond. Cambridge: Cambridge University Press, 1996.

O'NEILL, Terry \& PADEN JR., William. "Toward the Performance of Troubadour Poetry: Speaker and Voice in Peire Vidal". In: Educational Theatre Journal, vol. 30 (4), 1978, pp. 482-494.

PICCHIO, Luciana Stegagno. A Lição do Texto. Filologia e Literatura: I - Idade Média. Lisboa: Edições 70, 1979.

PICKENS, Rupert T. The Songs of Jaufre Rudel. Toronto: Pontifical Institute of Medieval Studies, 1978.

RESINA, Joan Ramon. "Hispanismo e Estado". In: Floema: Caderno de Teoria e História Literária, Vitória da Conquista, Especial 3 A, 2007, pp. 99-147.

RÜSEN, Jörn. "Historiografia comparativa intercultural”. In: MALERBA, Jurandir (Org.). A História Escrita: Teoria e história da historiografia. São Paulo: Contexto, 2006, pp. 115-137. 


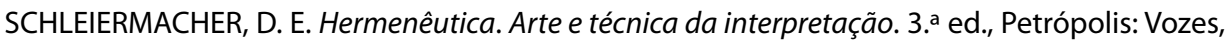
2001.

SPAGGIARI, Barbara \& PERUGI, Maurizio. Fundamentos da Crítica Textual: História, metodologia, exercícios. Rio de Janeiro: Lucerna, 2004.

SPINA, Segismundo. Introdução à Edótica. São Paulo: Ars Poetica/Edusp, 1994.

STAROBINSKI, Jean. "A Literatura: O texto e o seu intérprete". In: LE GOFF, Jacques \& NORA, Pierre (Ed.). História: Novas abordagens. São Paulo: Livraria Francisco Alves, 1988, pp. 132-143.

STEINLE, Eric M. “The Protean Voice: Textual Integrity and Poetic Structure in the Trouvère Lyric, Using an Example by Gace Brulé". In: Pacific Coast Philology, vol. 20 (1/2), 1985, pp. 89-95.

TIMPANARO, Sebastiano. La Genesi del Metodo del Lachamann. Seconda Ristampa, Padova: Liviana Editrice, 1990.

WEHLING, Arno. "Historiografia e epistemologia histórica”. In: MALERBA, Jurandir (Org.). A História Escrita: Teoria e história da historiografia. São Paulo: Contexto, 2006, pp. 175-189.

ZERNER, Henri. "A Arte". In: LE GOFF, Jacques \& NORA, Pierre (Ed.). História: Novas abordagens. São Paulo: Livraria Francisco Alves, 1988, pp. 144-159.

ZUMTHOR, Paul. Essai de poétique médiévale. Paris: Éditions du Seuil, 1972.

ZUMTHOR, Paul. “Intertextualité et mouvance”. In: Littérature, Paris, vol. 41, 1981, pp. 8-16.

ZUMTHOR, Paul. A Letra e a Voz: A literatura medieval. São Paulo: Companhia das Letras, 1993.

ZUMTHOR, Paul. “A poesia e o corpo”. In: Escritura e Nomadismo. São Paulo: Ateliê Editorial, 2005. 